\title{
1 UK shallow ground temperatures for ground coupled heat exchangers
}

\author{
Jon Busby
}

British Geological Survey, Keyworth, Nottingham, NG12 5GG, UK.

Emailjpbu@bgs.ac.uk

\begin{abstract}
Accurate estimations of shallow ground temperatures are required when sizing the horizontal closed loops and air supply culverts of ground coupled heating and cooling systems. These collector loops and culverts are within the zone affected by the seasonal swing in temperatures. Soil temperatures from 106 Met Office weather stations, located across the UK, have been analysed from which mean annual, seasonal minimum and maximum and daily minimum and maximum temperatures have been calculated. Mean annual temperatures at 1 $\mathrm{m}$ depth, reduced to sea level, range from $12.7^{\circ} \mathrm{C}$ in southern England to $8.8^{\circ} \mathrm{C}$ in northern Scotland, with corresponding seasonal ranges in temperature of $10.3{ }^{\circ} \mathrm{C}$ and $7.9{ }^{\circ} \mathrm{C}$ respectively. An average Urban Heat Island (UHI) effect at $1 \mathrm{~m}$ depth of $0.55{ }^{\circ} \mathrm{C}$ has been observed at localities adjacent to urban green spaces, from which it can be assumed that the UHI effect will be greater in densely developed city and town centres. A linear relation has been derived for the mean annual temperature at any non-urban UK locality, at $1 \mathrm{~m}$ depth. The seasonal temperature cycle has been extrapolated accurately to several metres depth with site specific thermal properties derived from the soil temperature measurements.
\end{abstract}

When designing closed-loop horizontal and vertical ground heat exchangers the temperature of the ground is a crucial parameter for correctly sizing the loops, whether the system is to be used for heating and/or cooling. Accurate ground temperatures are also required for passive heating and cooling systems, which temper ventilation air by introducing it through a large, buried air supply culvert, and this requires accurate knowledge of the seasonal temperature variations in the top $5 \mathrm{~m}$ of the ground (Orme \& Isanska-Cwiek 2012). The temperature in the ground at around $15 \mathrm{~m}$ depth is equal to the mean annual air temperature (Rybach \& Sanner 2000). At sea level for mainland UK, mean annual air temperature varies from north to south from about 8 to $12{ }^{\circ} \mathrm{C}$ (Perry \& Hollis 2005). Air temperatures are mainly affected by position and elevation. The decrease of air temperature with increasing altitude is given by the Environmental Lapse Rate which has an average value of $0.65{ }^{\circ} \mathrm{C}$ per $100 \mathrm{~m}$ (ICAO 1993). Temperatures in the ground beneath the zone affected by seasonal fluctuations (i.e., $>$ $15 \mathrm{~m}$ depth) will increase with depth depending on the local heat flow and the thermal conductivity of the ground. The average increase, referred to as the geothermal gradient, for the UK is $2.6{ }^{\circ} \mathrm{C}$ per $100 \mathrm{~m}$. Assuming that heat transfer is only by conduction, Busby et al. (2009) generated temperatures for Great Britain at $100 \mathrm{~m}$ depth that showed a range of 4 to $17{ }^{\circ} \mathrm{C}$. Within hydraulically transmissive rocks, heat can also be transferred by advection. Headon et al. (2009) report temperatures ranging from $11-15{ }^{\circ} \mathrm{C}$ at constant depths below ground level of 80 and $100 \mathrm{~m}$ within the Chalk aquifer below London. The higher temperatures in the SW of their study area are compatible with the geothermal gradient, but the lower temperatures in the east were speculatively attributed to recharge of cooler water. Pike et al. (2011) report a more extensive set of temperature measurements in the Chalk aquifer of the western London Basin syncline. At $100 \mathrm{~m}$ below ground level, temperatures varied from $9-9.5{ }^{\circ} \mathrm{C}$ to $14.5-15{ }^{\circ} \mathrm{C}$. This range in temperatures was partly attributed to ground surface elevation, but the higher temperatures were not fully explained; one possibility being that the Tertiary sequence overlying the Chalk may have a lower bulk thermal conductivity, and hence insulating effect, than would be expected. 
47 Horizontal ground loop collectors are buried either in a trench of sufficient width to allow the

48 pipe to be looped horizontally along its base or looped vertically in a slit trench. Suggested

49 depths of the trenches vary, for instance, Banks (2008) indicates 1.2-2 m, the IGSHPA (1996)

50 rule of thumb is 1.2-1.8 $\mathrm{m}$ and VDI (2001) suggest $1.2-1.5 \mathrm{~m}$. The trenches are within ground that is affected by the daily and seasonal temperature fluctuations, although the daily fluctuation only penetrates a few tens of centimetres (Banks 2008). It is a requirement (MIS 3005 2013) for the swing of ground temperatures through the year to be incorporated in ground source heat pump design so that base load and peak load requirements are met. The amplitude of the seasonal temperature swing decreases, and is offset in time, with depth (Banks 2008).

Maps of average soil temperatures at $30 \mathrm{~cm}$ depth are available from the Met Office based on monthly, seasonal or annual averages (http://www.metoffice.gov.uk/public/weather/climate/). There are also online agricultural services that will generate a soil temperature at $10 \mathrm{~cm} \mathrm{depth}$ for a UK postcode based on the average of the 5 closest Met Office weather stations (e.g. https://www.kws-uk.com/go/id/fnbz) or apps that will give a monthly or annual average soil temperature (e.g. http://www.bgs.ac.uk/mySoil/). However, none of these services give temperatures for $100 \mathrm{~cm}$ depth, the average depth of a horizontal ground loop collector.

It has been widely reported that urban areas, especially large towns and cities, have raised mean annual air temperatures when compared to rural areas (e.g., Pollack et al. 1998; Magee et al. 1999; Perrier et al 2005; Taniguchi et al. 2007). This is due to a variety of factors including, large tarmacadam/paved areas that preferentially absorb solar energy compared to vegetation, re-radiation of thermal energy at night from buildings warmed during the day and heat leakage from poorly insulated buildings (Linacre \& Geerts 1997). Higher mean air temperatures will also affect sub-surface temperatures that will also be enhanced by heat leakage from the floors and basements of buildings (Ferguson \& Woodbury 2004; Ferguson $\&$ Woodbury 2007) and heat discharged from underground services, especially water and sewage pipes (Banks et al. 2009). This thermal anomaly is known as the urban heat island (UHI) effect (Oke 1973). It represents an increased sub-surface thermal resource that can be exploited by thermal ground coupling technology (Zhu et al. 2010), but can create problems for those designing ground coupled passive heating and cooling systems where accurate ground temperatures are required.

Most urban sub-surface temperature measurements have been made in boreholes. Banks et al. (2009) report an increase of around $2-3{ }^{\circ} \mathrm{C}$ at $20 \mathrm{~m}$ depth in two closed loop boreholes in Gateshead, Tyne and Wear, UK. Ferguson \& Woodbury (2007) measured temperatures in 40 water wells in Winnipeg, Manitoba, Canada, from which they constructed a groundwater contour map at $20 \mathrm{~m}$ depth. This showed a general increase of $2-3{ }^{\circ} \mathrm{C}$ in the city centre compared to agricultural areas, but subsurface temperatures beneath green spaces in the city were lower than beneath business districts in the city centre. Menberg et al. (2013) examined shallow groundwater temperatures under six German cities and found regional differences in elevated temperatures between urban and rural areas of 3-7 ${ }^{\circ} \mathrm{C}$. In Berlin, Munich and Cologne, the highest temperatures were close to or in the city centre, whilst in Karlsruhe and Darmstadt they were found in industrial areas and close to landfill sites. In three investigated cities in Finland, Arola \& Korkka-Niemi (2014) found the average groundwater temperatures, below the seasonal fluctuation zone, were $1.3-2.0^{\circ} \mathrm{C}$ higher in the urban area and $3.0-4.0^{\circ} \mathrm{C}$ higher in the city centre than in the rural area around them.

There is very little in the literature on the UHI effect in the top $5 \mathrm{~m}$ of the ground. At these shallow depths, temperatures are affected by the seasonal swing in air temperature. The location of the site (i.e. proximity to green space) is likely to have an increased influence 
95 compared to temperatures at greater depths and the UHI effect may itself have a seasonal 96 component.

97 This Technical Note presents soil temperature data from Met Office stations across the UK to 98 a depth of $100 \mathrm{~cm}$. The data is intended to assist those who require accurate shallow 99 temperature data. Predictive trends are identified and some initial indications of the UHI 100 effect in the top $5 \mathrm{~m}$ of the ground are investigated.

\section{Methodology}

102 Soil temperature data are collected and archived by the UK Met Office at several hundred 103 weather stations and are made available for academic purposes via the British Atmospheric

104 Data Centre (http://badc.nerc.ac.uk/home). The data are recorded at 09:00 each day at depths 105 of 5, 10, 20, 30, 50 and $100 \mathrm{~cm}$, although not all depths are covered at each station and some 106 temperature depth records may be discontinuous. The data are recorded to the nearest $0.1{ }^{\circ} \mathrm{C}$. 107 In general, these sites are on level ground with no trees, buildings or steep ground nearby 108 (Met Office 2010). A typical soil temperature record for 5 years from the Met Office weather 109 station at Eastbourne with daily temperature readings at $30 \mathrm{~cm}$ depth (black lines) and 100 $110 \mathrm{~cm}$ depth (grey lines) is shown in Figure 1. There is considerable daily temperature 111 fluctuation and hence a function of the form;

$$
Y=a 0+a 1 \cos (w X)+b 1 \sin (w X)
$$

113 has been fitted to the data (see the bold lines in Figure 1) in order to identify seasonal trends.

114 From these daily data the following temperatures are derived:

115 Mean annual -

116

117 Seasonal minimum -

118

119

120

121

122

123

124

125

126

127

128

129

130

131

132

133

134

135

136

137

138

139

Seasonal maximum -

Daily minimum -

Daily maximum -
The mean temperature over several continuous full years between 2000-2010 at depths of 30,50 and $100 \mathrm{~cm}$.

The minimum temperature of the fitted function at depths of 30,50 and $100 \mathrm{~cm}$.

The maximum temperature of the fitted function at depths of 30,50 and $100 \mathrm{~cm}$.

The minimum daily temperature recorded over the period from which the mean was calculated, at depths of 30,50 and $100 \mathrm{~cm}$.

The maximum daily temperature recorded over the period from which the mean was calculated, at depths of 30,50 and $100 \mathrm{~cm}$.

If heat transfer into the ground is solely by conduction then the mean temperatures at two depths should be equal (since the contribution from the geothermal gradient is negligible at 0.02-0.04 ${ }^{\circ} \mathrm{C} / \mathrm{m}$ ). Differences indicate the influence from other heat transfer processes such as evapotranspiration and advection. If taken over several full years, the mean should not be too affected by exceptionally cold or warm years. The seasonal minimum and maximum temperatures represent average cold and warm conditions that can assist in designing a ground loop for peak load conditions. Extreme temperatures are given by the daily minimum and maximum temperatures and these will be more dependent on the time period considered. Extreme temperatures in the UK usually only last for a few days, although in exceptional conditions they can last for weeks or even months. These daily extremes may need to be considered when designing for peak load conditions for a vertically looped horizontal collector, but should have dissipated to low levels at the depth of a horizontally coiled collector. As discussed above, the seasonal temperature fluctuation in the ground decreases in amplitude and increases in phase shift (time offset) with depth. This can be seen clearly in the fitted curves in Figure 1. For two vertically separated soil temperature measurements 
140 resulting from a periodic heating cycle (e.g. the yearly cycle), the amplitude and phase 141 changes can be used to derive the thermal diffusivity of the soil (Kappelmeyer \& Haenel 142 1974; Adams et al. 1976; Horton et al. 1983). This is not included here, but a full account is 143 given in Busby (2015).

144 Soil temperature data from 106 UK Met Office weather stations have been analysed and their 145 distribution is shown in Figure 2. Geographical information on these 106 stations is presented 146 in Table A1 in the Appendix. They cover the full geographical extent of the UK and include 147 coastal and urban settings. Datasets for the period 2000-2010 have been analysed with an 148 emphasis on temperatures from $100 \mathrm{~cm}$ depth (the average depth of a horizontal loop trench), 149 although data are also presented from depths of 30 and $50 \mathrm{~cm}$. Only continuous yearly 150 sequences were used to determine the derived temperatures.

\section{Results}

152 Tabulated results for each Met Office weather station are presented for England, Scotland, 153 Wales and Northern Ireland in Tables A2-A5 in the appendix. In England, mean temperatures 154 at $100 \mathrm{~cm}$ depth decrease from around $12{ }^{\circ} \mathrm{C}$ in the south to $10{ }^{\circ} \mathrm{C}$ in the north with a 155 minimum of $9{ }^{\circ} \mathrm{C}$ at Shap and a maximum of $13{ }^{\circ} \mathrm{C}$ at St James' Park, London. Although 156 Shap is at an altitude of $255 \mathrm{~m}$, Buxton is higher at $307 \mathrm{~m}$, but the corresponding temperature 157 is $9.8^{\circ} \mathrm{C}$ and is due to the urbanised setting at Buxton and the exposed location at Shap. The 158 lowest seasonal minimum at $100 \mathrm{~cm}$ depth of $3.8^{\circ} \mathrm{C}$ occurs at Shap and the largest maximum 159 of $18.6^{\circ} \mathrm{C}$ occurs at both Littlehampton and St James' Park (both urban settings). A seasonal 160 maximum of $18.5^{\circ} \mathrm{C}$ occurs at Westleton, a non-urban setting on the East Anglian coast. The 161 seasonal minimums at $30 \mathrm{~cm}$ depth occur between $24^{\text {th }}$ January- $3^{\text {rd }}$ February and the 162 maximums between $25^{\text {th }}$ July- $4^{\text {th }}$ August. At $100 \mathrm{~cm}$ depth, these minimum and maximum 163 temperatures are delayed to $30^{\text {th }}$ January-22 ${ }^{\text {nd }}$ February and $31^{\text {st }}$ July-22 ${ }^{\text {nd }}$ August, 164 respectively. The daily minimum at $100 \mathrm{~cm}$ depth is $1.5^{\circ} \mathrm{C}$ at Warcop Range, $19 \mathrm{~km}$ from 165 Shap and the maximum is $21.6^{\circ} \mathrm{C}$ at both St James' Park and Oxford (both urban settings).

166 For Scotland, the range in mean temperatures at $100 \mathrm{~cm}$ depth is from around $10{ }^{\circ} \mathrm{C}$ in the 167 south to $9^{\circ} \mathrm{C}$ in the north with a minimum of $8.2^{\circ} \mathrm{C}$ at Braemar (at an altitude of $339 \mathrm{~m}$ ) and a 168 maximum of $11.1^{\circ} \mathrm{C}$ at Paisley (an urban setting). The lowest seasonal minimum at $100 \mathrm{~cm}$ 169 depth of $3^{\circ} \mathrm{C}$ occurs at Aviemore and the largest maximum of $15.9^{\circ} \mathrm{C}$ occurs at Paisley. The 170 seasonal minimums at $30 \mathrm{~cm}$ depth occur between $23^{\text {rd }}$ January- $7^{\text {th }}$ February and the 171 maximums between $24^{\text {th }} \mathrm{July}-7^{\text {th }}$ August. At $100 \mathrm{~cm}$ depth, these minimum and maximum 172 temperatures are delayed to $7^{\text {th }}-23^{\text {rd }}$ February and $7^{\text {th }}-23^{\text {rd }}$ August, respectively. The daily 173 minimum at $100 \mathrm{~cm}$ depth is $1.2^{\circ} \mathrm{C}$ at Aviemore and the maximum is $18^{\circ} \mathrm{C}$ at Paisley.

174 There are fewer data for Wales and these show a range in mean temperatures at $100 \mathrm{~cm}$ depth 175 from around $12{ }^{\circ} \mathrm{C}$ in the south to $10.5{ }^{\circ} \mathrm{C}$ in the north with a minimum of $10.4{ }^{\circ} \mathrm{C}$ at 176 Loggerheads and a maximum of $12.3^{\circ} \mathrm{C}$ at Penmaen. The lowest seasonal minimum at 100 $177 \mathrm{~cm}$ depth of $5.4{ }^{\circ} \mathrm{C}$ occurs at Loggerheads and the largest maximum of $17.6{ }^{\circ} \mathrm{C}$ at Penmaen. 178 The seasonal minimums at $30 \mathrm{~cm}$ depth occur between $30^{\text {th }}$ January- $2^{\text {nd }}$ February and the 179 maximums between $30^{\text {th }} \mathrm{July}-3^{\text {rd }}$ August. At $100 \mathrm{~cm}$ depth, these minimum and maximum 180 temperatures are delayed to $11^{\text {th }}-15^{\text {th }}$ February and $12^{\text {th }}-15^{\text {th }}$ August, respectively. The daily 181 minimum at $100 \mathrm{~cm}$ depth is $3.3^{\circ} \mathrm{C}$ at Bala and the maximum is $18.9^{\circ} \mathrm{C}$ at Penmaen.

182 In Northern Ireland, the minimum mean temperature at $100 \mathrm{~cm}$ depth is $10.3{ }^{\circ} \mathrm{C}$ at Coleraine 183 and the maximum is $11.2^{\circ} \mathrm{C}$ at Annaghmore. The lowest seasonal minimum and largest 184 maximum at $100 \mathrm{~cm}$ depth of $5.7^{\circ} \mathrm{C}$ and $16.4{ }^{\circ} \mathrm{C}$, respectively, both occur at St Angelo. The 185 seasonal minimums and maximums at $100 \mathrm{~cm}$ depth occur between $8^{\text {th }}-19^{\text {th }}$ February and $9^{\text {th }}$. 
$18620^{\text {th }}$ August, respectively. The daily minimum and maximum temperatures at $100 \mathrm{~cm}$ depth of $1873.8^{\circ} \mathrm{C}$ and $17.4^{\circ} \mathrm{C}$, respectively, also both occur at St Angelo.

188 To facilitate comparison, the means and seasonal minimums and maximums at $100 \mathrm{~cm}$ depth 189 have been reduced to sea level with a correction of $0.65^{\circ} \mathrm{C}$ per $100 \mathrm{~m}$ and are shown in Table 190 1. Between southern and northern England, the range in mean temperature at $100 \mathrm{~cm}$ depth is $1912.1{ }^{\circ} \mathrm{C}$, whilst the range in seasonal minimums and maximums is $2.5{ }^{\circ} \mathrm{C}$ and $3.1{ }^{\circ} \mathrm{C}$, 192 respectively. The seasonal range in temperature in southern England is $10.3{ }^{\circ} \mathrm{C}$ and in 193 northern England $10.2{ }^{\circ} \mathrm{C}$. It should be noted that for central England there is no difference in 194 mean temperatures between east and west, at a corrected to sea level mean value of $11.5^{\circ} \mathrm{C}$. 195 Between southern and northern Scotland, the corresponding range in sea level corrected mean 196 temperature is $2.4^{\circ} \mathrm{C}$ and the range in seasonal minimums and maximums is $1.7^{\circ} \mathrm{C}$ and 4.0 $197{ }^{\circ} \mathrm{C}$, respectively. The seasonal range in temperature in southern Scotland is $9.7{ }^{\circ} \mathrm{C}$ and in 198 northern Scotland $7.9^{\circ} \mathrm{C}$. For Wales, the seasonal range in $100 \mathrm{~cm}$ sea level corrected 199 temperatures is $9.9^{\circ} \mathrm{C}$ and for Northern Ireland it is $8.8^{\circ} \mathrm{C}$.

200 Some initial indications of the UHI effect have been investigated here by comparing mean 201 annual temperatures at $100 \mathrm{~cm}$ depth between urban locations and, near-by, rural locations. 202 For the comparisons, temperatures have only been considered over the same time period at 203 the urban and rural sites and the temperature at the rural location has been corrected for the 204 elevation difference to the urban site using the Environmental Lapse Rate of $0.65{ }^{\circ} \mathrm{C}$ per 100 $205 \mathrm{~m}$. The results are shown in Table 2. For the 10 comparisons considered, there is a 206 measurable UHI effect at eight of them, with only one site showing a cooler temperature at 207 the urban location. The maximum UHI effect measured, at Bournemouth, is $1.0^{\circ} \mathrm{C}$, and the 208 average is $0.55^{\circ} \mathrm{C}$. Met Office weather stations in the urban environment are located on the 209 edges of green spaces (parks, school playing fields, etc.). Hence, from the evidence cited 210 above from borehole temperature measurements, it must be assumed that an increased UHI 211 effect would be expected in the city/town centres. The highest mean annual temperatures 212 were recorded at St James' Park, a green space in the centre of London. Unfortunately there 213 is no near-by rural location with temperature data at $100 \mathrm{~cm}$ depth, but a comparison can be 214 made with Aldenham School for $30 \mathrm{~cm}$ depth data, resulting in an UHI effect at St James' 215 Park of $2.2^{\circ} \mathrm{C}$.

216 In Table 3, the same analysis has been applied to the seasonal minimums and maximums with 217 comparisons between urban and elevation-corrected rural temperatures. For six of the eight 218 urban locations that showed an UHI effect, the seasonal maximum has a greater UHI effect 219 than the seasonal minimum, suggesting the effect is more dominant at very shallow depths in the summer. However, for two of the locations showing an UHI effect (Bradford and Paisley) this is reversed, as it is also for the two locations (Reading and Cambridge) that did not show an UHI effect.

Discussion

224 These data provide some insights into the variation of sub-surface temperatures within the top 225 one metre of the ground, across the UK. Latitude and elevation are the main parameters that 226 influence temperature. Mean annual temperatures corrected to sea level at $100 \mathrm{~cm}$ depth, vary 227 from $12.7^{\circ} \mathrm{C}$ in the south of the UK to $8.8^{\circ} \mathrm{C}$ in the north, although higher temperatures can occur in towns and cities. The range in average seasonal temperatures, i.e. the difference between warm summer and cold winter, corrected to sea level at $100 \mathrm{~cm}$ depth, varies from $10.3{ }^{\circ} \mathrm{C}$ in southern England to $7.9^{\circ} \mathrm{C}$ in northern Scotland. At a metre depth, for the UK, the coldest time of year is February and the warmest is August. The Met Office weather stations are not ideally placed to measure an UHI effect as, within urban areas, they are located adjacent to green spaces. However, where an effect was recognised, there is an average 
increase in temperature at 1 metre depth of $0.55^{\circ} \mathrm{C}$. By comparisons with other studies at greater depth, it must be assumed that the UHI effect will be higher in highly urbanised city and town centres.

237 For 12 of the stations located across the UK, the mean annual air temperature has been 238 calculated for the same time periods used to calculate the temperatures at $100 \mathrm{~cm}$ depth. These are shown in Table 4, along with the mean annual temperatures at $100 \mathrm{~cm}$ depth. In all cases the soil temperature is greater than the mean annual air temperature and the range is 0.5-2.0 ${ }^{\circ} \mathrm{C}$. The average of these 12 comparisons is $0.9{ }^{\circ} \mathrm{C}$, which is in agreement with accepted practice that mean annual soil temperatures are slightly higher than mean annual air temperatures (e.g. Banks 2008).

In Figure 3 the mean annual temperatures at $100 \mathrm{~cm}$ depth for non-urban locations, corrected to sea level, are plotted against northing. There is a clear, linear trend, but with some scatter that will be due to other factors that affect the soil temperature, e.g. local topography and aspect. A linear trend has been fitted to these data that is also shown on Figure 3. From this fit it is possible to predict the mean temperature for non-urban locations at $100 \mathrm{~cm}$ depth as;

$$
\text { temp }=\left(-3.539 \times 10^{-6} \times \text { northing }\right)+12.8-(\text { elevation } \times 0.0065) \pm 0.3 \text {, }
$$

where temp is the predicted temperature in ${ }^{\circ} \mathrm{C}$, at a location with a northing in $\mathrm{m}$, at an elevation above OD in $\mathrm{m}$. The quoted error of $\pm 0.3{ }^{\circ} \mathrm{C}$ is the standard deviation of the linear fit. For the Met Office stations used here, the maximum deviation between measured and predicted temperatures is $0.8^{\circ} \mathrm{C}$.

With these data it is also possible to generate accurate ground temperatures within the upper few metres of the ground and this is illustrated with data from the Wallingford Met Office weather station. The extrapolation of temperature with depth due to periodic surface heating is given by Beardsmore \& Cull (2001) as,

$$
T_{\theta}=T_{0} \exp (-\varepsilon z) \sin (\omega t-\varepsilon z)
$$

where $T_{\theta}$ is the departure from a mean value of temperature at a particular depth, $z$, and time, $t$, due to a heating cycle with amplitude $T_{0}$ and frequency $\omega$. For Wallingford, the heating cycle is taken as the seasonally fitted temperature curve at $50 \mathrm{~cm}$ depth. The thermal properties of the medium are included in the $\varepsilon$ term where $\varepsilon=(\pi / \mathrm{P} \kappa)^{1 / 2}$, where $\mathrm{P}$ is the period of the heating cycle and $\kappa$ is the thermal diffusivity of the ground. As mentioned above, thermal diffusivity can be estimated from two vertically separated temperature measurements and for Wallingford, utilising the temperatures at 50 and $100 \mathrm{~cm}$ depths, the value for $\kappa$ is $6.754 \times 10^{-7} \mathrm{~m}^{2} \mathrm{~s}^{-1}$ (Busby 2015). The amplitude of the heating cycle at $50 \mathrm{~cm}$ depth, $\mathrm{T}_{0}$, is equal to $5.47^{\circ} \mathrm{C}$ and the mean value of temperature at $50 \mathrm{~cm}$ depth is equal to $11.71{ }^{\circ} \mathrm{C}$ (see Table A2 in the Appendix). The resulting extrapolated temperatures from 0 to $5 \mathrm{~m}$ depths are shown in Figure 4. The phase offset was aligned from the known offset between the 50 and $100 \mathrm{~cm}$ depth seasonally fitted temperature curves. It should also be noted that the extrapolated curve at $1 \mathrm{~m}$ depth fits the $100 \mathrm{~cm}$ depth seasonally fitted curve to within \pm 0.1 ${ }^{\circ} \mathrm{C}$. Hence, at Wallingford, the seasonal range in temperature is $13.3{ }^{\circ} \mathrm{C}$ at $0 \mathrm{~cm}$ depth, which is dampened to $4.2^{\circ} \mathrm{C}$ at $3 \mathrm{~m}$ depth and $1.9^{\circ} \mathrm{C}$ at $5 \mathrm{~m}$ depth. The time offset in the peaks and troughs of the seasonal temperature cycle, compared to the temperature at $0 \mathrm{~cm}$ depth, is 67 days at $3 \mathrm{~m}$ depth and 112 days at $5 \mathrm{~m}$ depth. Beardsmore \& Cull (2001) define the effective wavelength $\left(\mathrm{Z}_{\mathrm{wl}}=(4 \pi \mathrm{P} \kappa)^{1 / 2}\right)$ as the depth at which the temperature fluctuation is in phase with that at $0 \mathrm{~cm}$ depth with a temperature perturbation equal to 0.0019 of that at $0 \mathrm{~cm}$ depth. This depth is considered to be the maximum depth to which seasonal temperature fluctuations need to be considered. At Wallingford, the effective wavelength is $16.4 \mathrm{~m}$ with a temperature perturbation of $0.03{ }^{\circ} \mathrm{C}$. 
282 The UK Government is committed to carbon emission reductions and a substantial increase 283 in heat provided by renewables, including ground source heat (DECC 2013). The EU requires that Member States shall ensure that by 31 December 2020 all new buildings are nearly zeroenergy buildings and the nearly zero or very low amount of energy required should be covered to a very significant extent by energy from renewable sources (EU 2010). It is therefore expected that there will be a substantial increase in the number of ground coupled heating systems installed in the UK over the next decade. Those planning or designing such systems require information and tools to assist them. For instance, Abesser et al. (2014) have produced an on-line tool for an initial assessment of the suitability of a site for open loop GSHP at the scale of a commercial building. Knowledge of shallow ground temperatures is also important in contaminated land studies since temperature is an important determinant in the rate of biodegradation (e.g. Leahy \& Colwell 1990; Benoit et al. 2007; Yadav \& Hassanizadeh 2011)

The data presented here are primarily intended to assist in the design of very shallow ground coupled heating systems where the seasonal swing of ground temperatures has to be taken into consideration. Soil temperatures from 106 Met Office stations have been analysed and tabulated data have been presented of the mean annual and seasonal temperatures, and the expected daily minimum and maximum temperatures, within the top one metre of the ground across the UK. Mean annual soil temperatures are, on average, $1{ }^{\circ} \mathrm{C}$ higher than mean annual air temperatures. Mean annual temperatures at $1 \mathrm{~m}$ depth, reduced to sea level, range from 12.7 ${ }^{\circ} \mathrm{C}$ in southern England to $8.8{ }^{\circ} \mathrm{C}$ in northern Scotland, with corresponding seasonal ranges in temperature of $10.3{ }^{\circ} \mathrm{C}$ and $7.9{ }^{\circ} \mathrm{C}$, respectively. An average UHI effect at $1 \mathrm{~m}$ depth of $0.55{ }^{\circ} \mathrm{C}$ has been observed at localities adjacent to urban green spaces, from which it can be assumed that the UHI effect will be greater in densely developed city and town centres.

A linear relation has been derived from which the mean annual temperature for any nonurban UK locality, at $1 \mathrm{~m}$ depth, can be calculated. Accurate temperatures to several metres depth are also sometimes required and this has been demonstrated, on a site specific basis, by extrapolating the seasonal temperature cycle to depth.

\section{Acknowledgements}

This paper is published by permission of the Executive Director of the British Geological Survey (NERC). The UK Met Office is thanked for making available the soil temperature data held in the Met Office Database - MIDAS and made available through the British Atmospheric Data Centre (BADC).

\section{References}

Abesser, C., Lewis, M. A., Marchant, A. P. \& Hulbert, A. G. 2014. Mapping suitability for open-loop ground source heat pump systems: a screening tool for England and Wales, UK. Quarterly Journal of Engineering Geology and Hydrogeology, 47, 373380. http://dx.doi.org/10.1144/qjegh2014-050

AdAms, W. M., WatTs, G. \& Mason, G. 1976. Estimation of thermal diffusivity from field observations of temperature as a function of time and depth. American Mineralogist, 61, 560-568.

Arola, T. \& KorkKa-NiEMI, K. 2014. The effect of urban heat islands on geothermal potential: examples from Quaternary aquifers in Finland. Hydrogeology Journal, 22, 1953-1967. 
BANKS, D. 2008. An Introduction to Thermogeology: Ground source heating and cooling. Oxford: Blackwell.

Banks, D., Gandy, C. J., Younger, P. L., Withers, J. \& Underwood, C. 2009. Anthropogenic thermogeological 'anomaly' in Gateshead, Tyne and Wear, UK. Quarterly Journal of Engineering Geology and Hydrogeology, 42, 307-312.

Beardsmore, G. R. \& Cull, J. R. 2001. Crustal heat flow: a guide to measurement and modelling. Cambridge: Cambridge University Press.

Benoit, P., Perceval, J., Stenrød, M., Moni, C., Eklo O. M., Barriuso, E., Sveistrup, T. \& KVÆRNER, J. 2007. Availability and biodegradation of metribuzin in alluvial soils as affected by temperature and soil properties. Weed Research, 47, 517-526.

BusBY, J. 2015. Determination of thermal properties for horizontal ground collector loops. Proceedings World Geothermal Congress 2015, Melbourne, Australia, 19-25 April 2015.

Busby, J., LEWIS, M., REEVES, H. \& LAWLEY, R. 2009. Initial geological considerationsbefore installing ground source heat pump systems. Quarterly Journal of Engineering Geology and Hydrogeology, 42, 295-306.

EU. 2010. DIRECTIVE 2010/31/EU OF THE EUROPEAN PARLIAMENT AND OF THE COUNCIL of 19 May 2010 on the energy performance of buildings (recast). Official Journal of the European Union, L153/13-35. http://eurlex.europa.eu/LexUriServ/LexUriServ.do?uri=OJ:L:2010:153:0013:0035:EN:PDF

DECC. 2013. The Future of Heating: Meeting the challenge. Department of Energy and Climate Change. https:/www.gov.uk/government/uploads/system/uploads/attachment_data/file/190149/ 16_04-DECC-The_Future_of_Heating_Accessible-10.pdf

Ferguson, G. \& Woodbury, A. D. 2004. Subsurface heat flow in an urban environment. Journal of Geophysical Research, 109, B02402, 9 pp.

Ferguson, G. \& Woodbury, A. D. 2007. Urban heat island in the subsurface. Geophysical Research Letters, 34, L23713.

Headon, J., Banks, D., Waters, A. \& Robinson, V. K. 2009. Regional distribution of ground temperature in the Chalk aquifer of London, UK. Quarterly Journal of Engineering Geology and Hydrogeology, 42, 313-323.

Horton, R., WiERENGA, P. J., \& NiElSEN, D. R. 1983. Evaluation of methods for determining apparent thermal diffusivity of soil near the surface, Journal of the American Soil Science Society, 47, 23-32.

ICAO. 1993. International Civil Aviation Organization, Manual of the ICAO Standard Atmosphere (extended to 80 kilometres (262 500 feet)), Doc 7488-CD, Third Edition, 1993, ISBN 92-9194-004-6.

IGSHPA. 1996. Closed-loop/Ground-Source Heat Pump Systems: Installation guide. Oklahoma State University: International Ground Source Heat Pump Association Publications.

KAPPELMEYeR, O. \& HAENEL, R. 1974. Geothermics with special reference to application. Geoexploration Monographs Series 1 - No 4, Gebruder Borntraeger: Berlin - Stuttgart $238 \mathrm{pp}$. 
Leahy, J. G. \& Colwell, R. R. 1990. Microbial Degradation of Hydrocarbons in the Environment. Microbiological Reviews, 54, 305-315.

LinACRE, E. \& GEERTS, B. 1997. Climates and Weather Explained. Routledge, London.

Magee, N., Curtis, J. \& Wendler, G. 1999. The urban heat island effect at Fairbanks, Alaska. Theoretical and Applied Climatology, 64, 39-47.

Menberg, K., Bayer, P., Zosseder, K., Rumohr, S. \& Blum, P. 2013. Subsurface urban heat islands in German cities. Science of the Total Environment, 442, 123-133.

Met OfFice. 2010. Observations. National Meteorological Library and Archive Fact Sheet 17 - Weather observations over land, www.metoffice.gov.uk/media/pdf/k/5/Fact_sheet_No._17.pdf.

MIS 3005. 2013. Microgeneration Installation Standard, MIS 3005: Requirements for contractors undertaking the supply, design, installation, set to work, commissioning and handover of microgeneration heat pump systems, Issue 4.1, www.microgenerationcertification.org.

OKE, T. R. 1973. City size and the urban heat island Atmospheric Environment, 7, 769-779.

ORME, M. \& ISANSKA-CWIEK, A. 2012. Solar-assisted ground coupling for a naturally ventilated school building. BSO12, First Building Simulation and Optimization Conference, Loughborough, UK, 10-11 September 2012, IBPSA-England, 124-131.

Perrier, F., Le Mouel, J. L., Poirier, J. P. \& Shnirman, M. G. 2005. Long-term climate change and surface versus underground temperature measurements in Paris. International Journal of Climatology, 25, 1619-1631.

Perry, M. \& Hollis, D. 2005. The development of a new set of long-term climate averages for the UK. International Journal of Climatology, 25, 1023-1039.

Pike, D., Banks, D., Waters, A. \& Robinson, V. K. 2011. Regional distribution of temperature in the Chalk of the western London Basin syncline. Quarterly Journal of Engineering Geology and Hydrogeology, 46, 117-125.

Pollack, H. N., Huang, S. P. \& Shen, P. Y. 1998. Climate change record in subsurface temperatures: a global perspective. Science, 282, 279-281.

RyBaCH, L. \& SANNER, B. 2000. Ground-source heat pump systems; the European experience. Geo-Heat Center Bulletin, 21, 16-26.

TANiguchi, M., Uemura, T. \& JAGO-ON, K. 2007. Combined effects of urbanization and global warming on subsurface temperature in four Asian cities. Vadose Zone Journal, 6, 591-596.

VDI. 2001. Thermal use of the underground: Ground source heat pump systems. Verein Deutscher Ingenieure. Richtlinien VDI 4640 Blatt2/Part2, September 2001, Düsseldorf $43 \mathrm{pp}$.

YADAV, B. K. \& HASSANIZADEH, S. M. 2011. An overview of biodegradation of LNAPLS in coastal (semi)-arid environment. Water Air Soil Pollution, 220, 225-239.

Zhu, K., Blum, P., Ferguson, G., Balke, K-D. \& Bayer, P. 2010. The geothermal potential of urban heat islands. Environmental Research Letters, 5, 044002, 6 pp. 


\section{Figure and Table captions}

2 Figure 1. Five year temperature record (from the $1^{\text {st }}$ January 2000) from the Met Office

3 weather station at Eastbourne. The black record is the temperature at $30 \mathrm{~cm}$ depth and the

4 grey record from $100 \mathrm{~cm}$ depth. The rapidly fluctuating records are the daily measurements

5 and the smooth records are the best fit through the data of an appropriate periodic function.

6 Figure 2. The locations of the 106 Met Office weather stations from which soil temperature 7 data have been utilised. The stations are numbered from 1 to 106 based on their northing. 8 Geographical information for the stations is presented in Table A1 in the Appendix.

9 Figure 3. Plot of the mean annual temperatures at $100 \mathrm{~cm}$ depth, for non-urban locations

10 corrected to sea level, plotted against northing. The best linear fit through the data is shown

11 by the solid line, which had a coefficient of determination of 0.9.

12 Figure 4. Seasonal soil temperature cycles at the Wallingford Met Office weather station. The

13 seasonally fitted temperatures at $50 \mathrm{~cm}$ depth have been extrapolated to depths $0-5 \mathrm{~m}$ based

14 on the periodic nature of the cycle. Site specific values of thermal diffusivity, mean value of

15 temperature at $50 \mathrm{~cm}$ depth and amplitude of the heating cycle at $50 \mathrm{~cm}$ depth are given in the 16 text.

17 Table 1. Mean annual and seasonal minimum and maximum temperatures at $100 \mathrm{~cm}$ depth 18 reduced to sea level.

19 Table 2. Estimation of the urban heat island (UHI) effect based on comparisons of mean annual temperatures at $100 \mathrm{~cm}$ depth between urban and, near-by, rural locations. Temperatures are over the same time period for each comparison and the temperature at the rural location has been corrected for the elevation difference to the urban site using the Environmental Lapse Rate of $0.65^{\circ} \mathrm{C}$ per $100 \mathrm{~m}$.

Table 3. Estimation of a seasonal UHI effect based on comparisons of seasonal temperatures at $100 \mathrm{~cm}$ depth between urban and, near-by, rural locations. Temperatures are over the same time period for each comparison and the temperature at the rural location has been corrected for the elevation difference to the urban site using the Environmental Lapse Rate of $0.65{ }^{\circ} \mathrm{C}$ per $100 \mathrm{~m}$.

Table 4. Comparisons between mean annual air temperatures and mean annual temperatures at $100 \mathrm{~cm}$ depth, calculated over the same time period for each comparison.

\section{Appendix Tables}

Table A1. Geographical information for the Met Office weather stations referred to in this paper. The record number (Rec) orders the stations based on northing and is used as the station identifier in Figure 2. The unique source identifier (src_id) is the Met Office station number. Eastings and northings are British National Grid and elevation is relative to OD (Ordnance Datum).

37 Table A2. Tabulated results of the mean annual (Mean), seasonal minimum $\left(\mathrm{S}_{\min }\right)$ and maximum $\left(S_{\max }\right)$, and daily minimum $\left(D_{\min }\right)$ and maximum $\left(\mathrm{D}_{\max }\right)$ temperatures for Met Office weather stations in England. The time period (in complete years) is the time over which the temperatures were calculated and the depth (in brackets to the right of the time period) is the depth of the temperature measurements.

42 Table A3. Tabulated results of the mean annual (Mean), seasonal minimum $\left(S_{\min }\right)$ and 43 maximum $\left(S_{\max }\right)$, and daily minimum $\left(D_{\min }\right)$ and maximum $\left(D_{\max }\right)$ temperatures for Met 44 Office weather stations in Scotland. Time period and depth are as described for Table A2. 
45 Table A4. Tabulated results of the mean annual (Mean), seasonal minimum $\left(\mathrm{S}_{\min }\right)$ and 46 maximum $\left(S_{\max }\right)$, and daily minimum $\left(D_{\min }\right)$ and maximum $\left(D_{\max }\right)$ temperatures for Met 47 Office weather stations in Wales. Time period and depth are as described for Table A2.

48 Table A5. Tabulated results of the mean annual (Mean), seasonal minimum $\left(\mathrm{S}_{\min }\right)$ and 49 maximum $\left(S_{\max }\right)$, and daily minimum $\left(\mathrm{D}_{\min }\right)$ and maximum $\left(\mathrm{D}_{\max }\right)$ temperatures for Met 50 Office weather stations in Northern Island. Time period and depth are as described for Table 51 A2. 


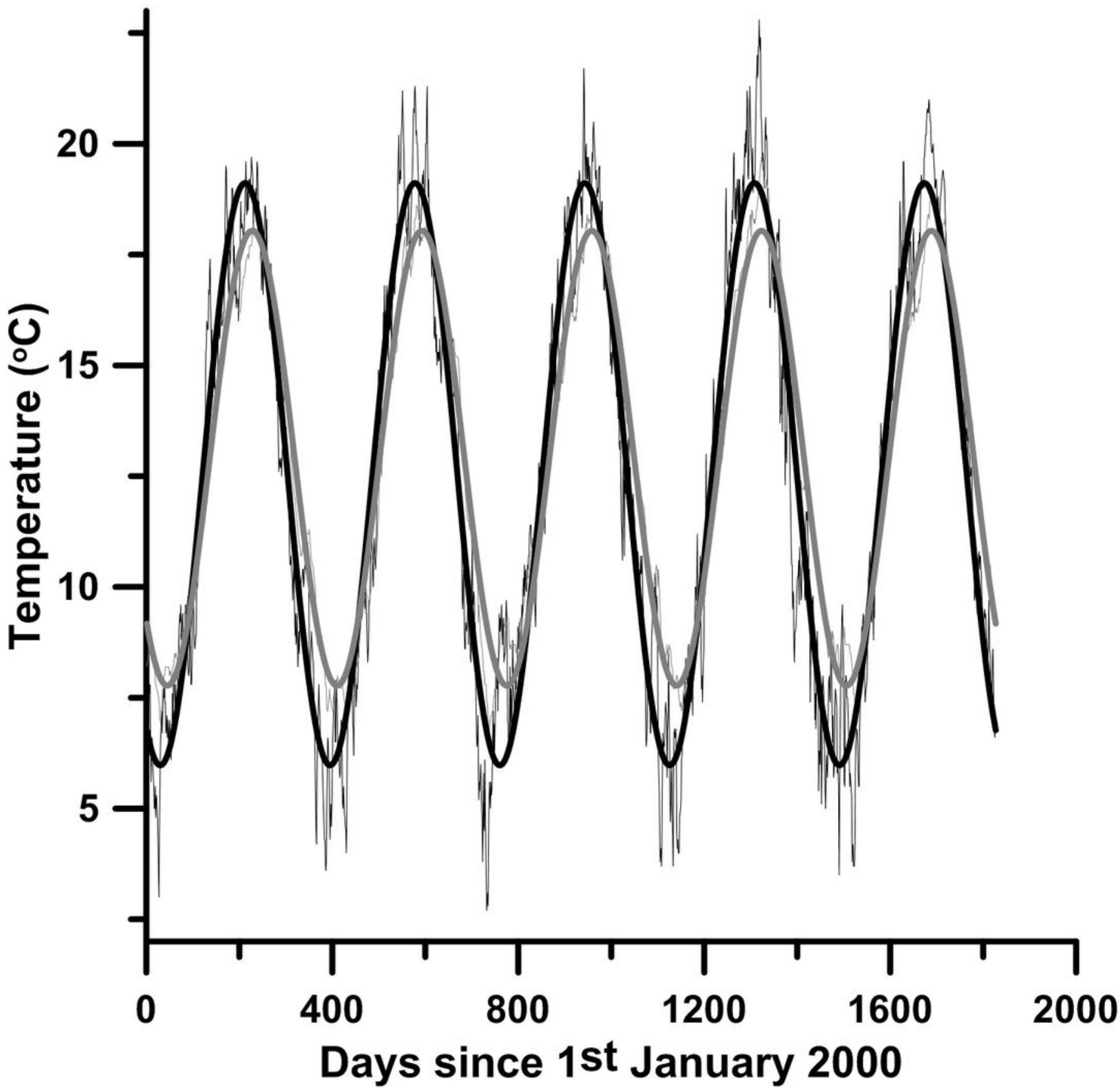




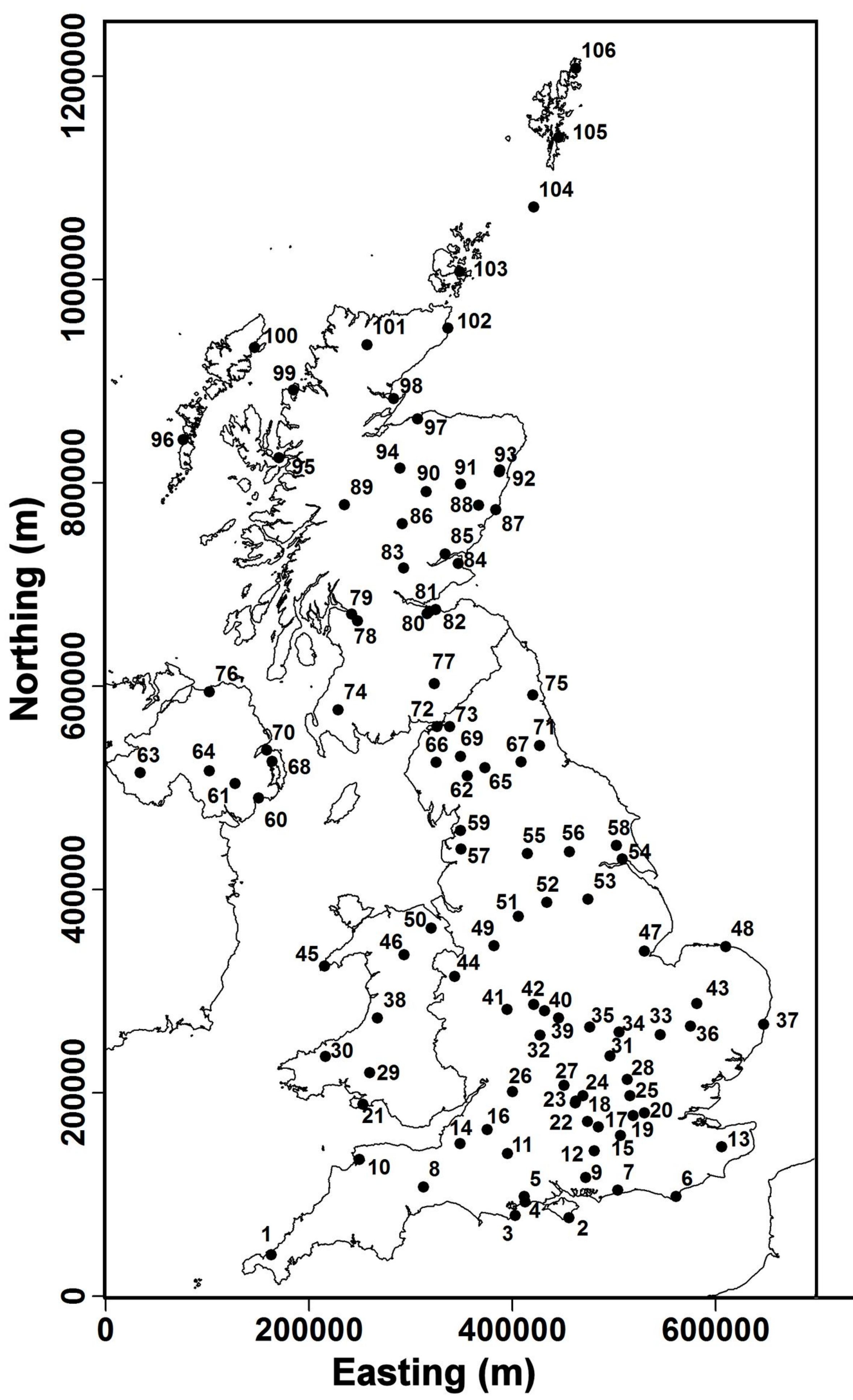




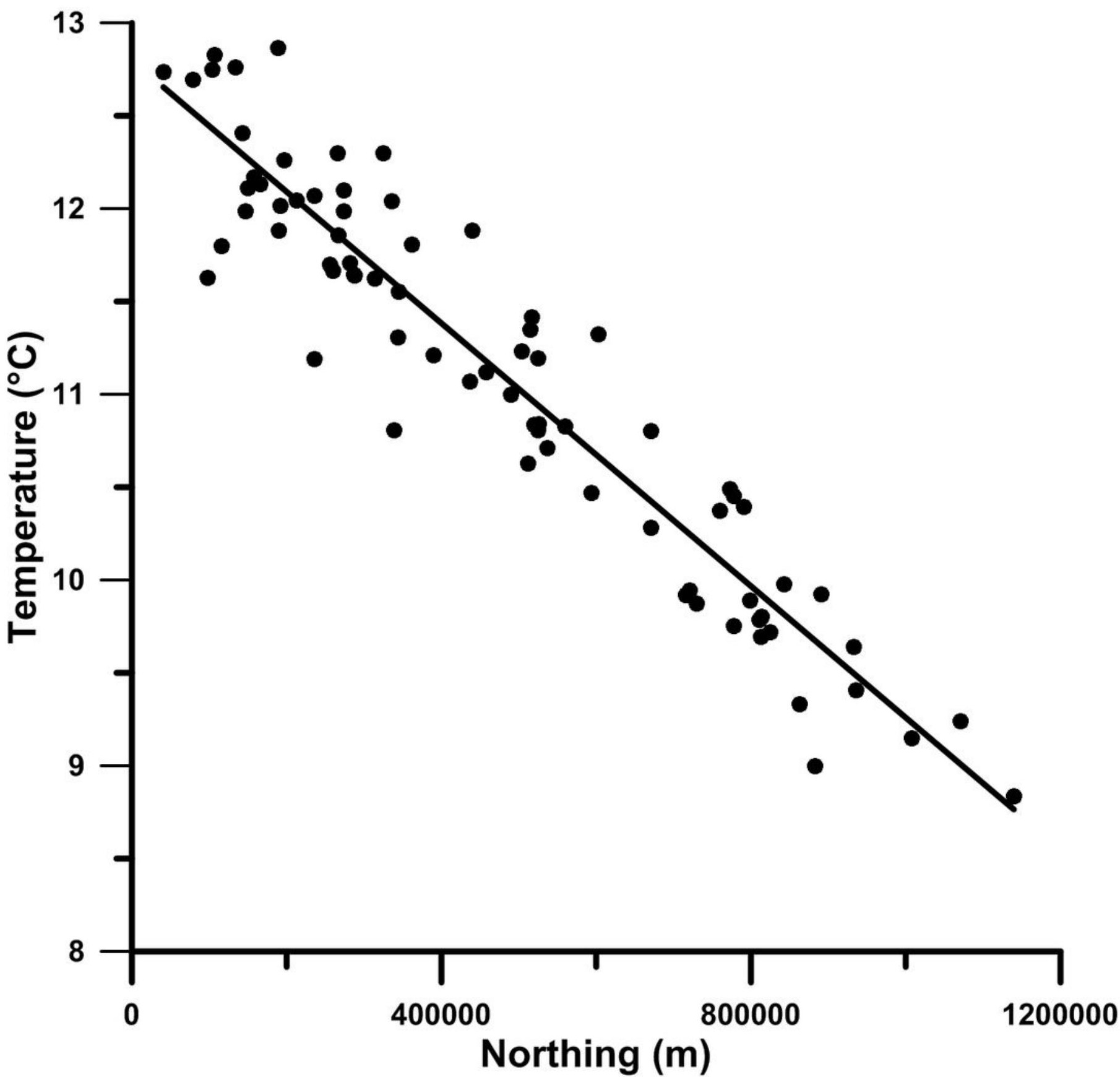




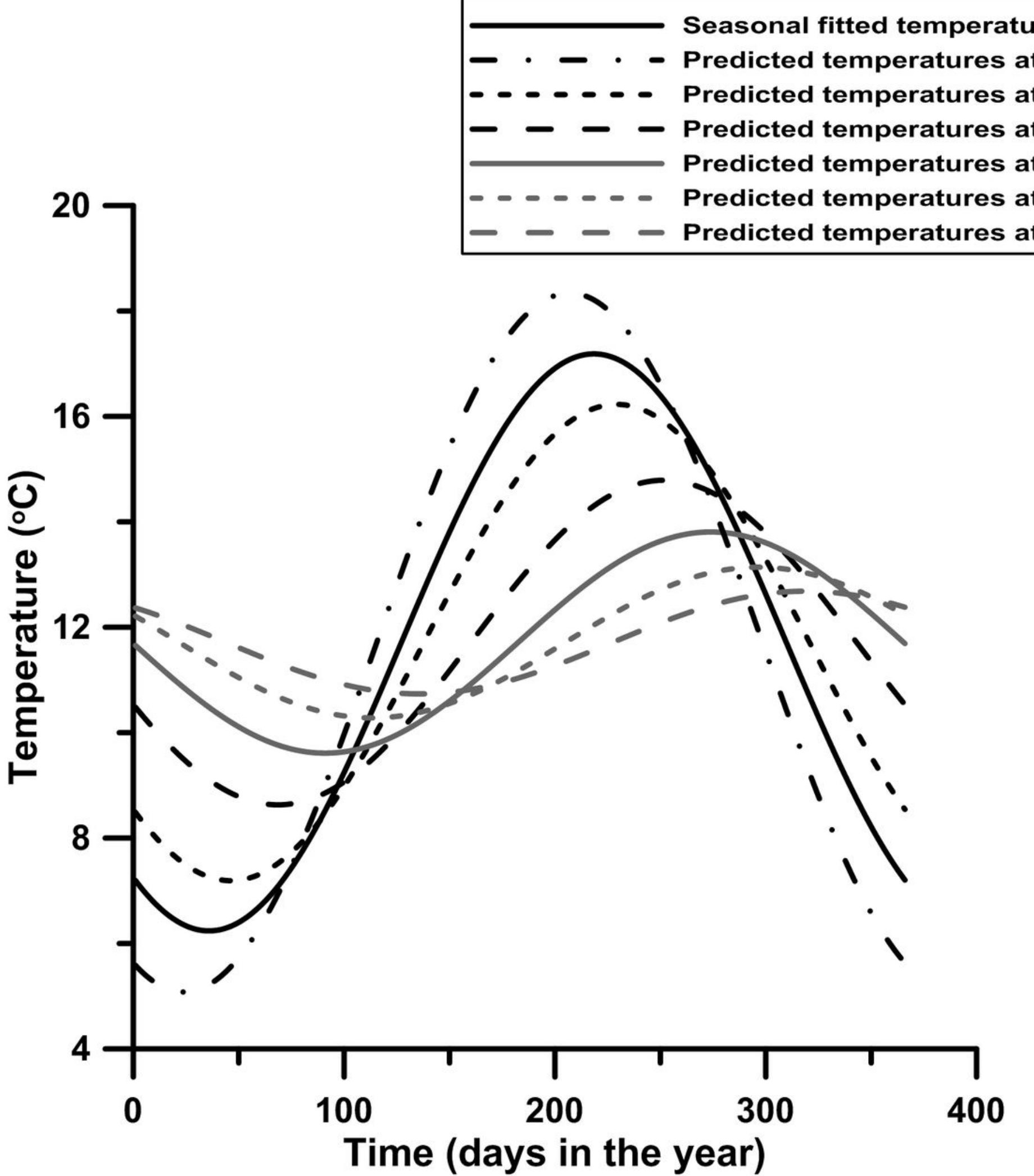




\begin{tabular}{|c|c|c|c|c|c|}
\hline \multicolumn{2}{|c|}{ Met station id } & \multirow[t]{2}{*}{ Abbreviated station name } & \multicolumn{3}{|c|}{$\begin{array}{c}\text { Sea level } 100 \mathrm{~cm} \\
\text { temps. }\left({ }^{\circ} \mathrm{C}\right)\end{array}$} \\
\hline $\operatorname{Rec}$ & Src_id & & Mean & $\mathbf{S}_{\min }$ & $\mathbf{S}_{\max }$ \\
\hline ENGLAND & 1395 & Camborne & 12.7 & 8.0 & 17.5 \\
\hline 3 & 1326 & Swanage & 12.7 & 8.1 & 17.3 \\
\hline 4 & 843 & Bournemouth & 12.7 & 7.2 & 18.3 \\
\hline 5 & 842 & Hurn & 11.6 & 6.5 & 16.7 \\
\hline 6 & 808 & Eastbourne & 12.9 & 7.8 & 18.1 \\
\hline 7 & 16608 & Littlehampton & 12.7 & 6.9 & 18.6 \\
\hline 8 & 1383 & Dunkeswell Aerodrome & 12.8 & 7.5 & 18.2 \\
\hline 9 & 865 & Butser, Windmill Hill & 11.8 & 6.8 & 16.8 \\
\hline 10 & 1346 & Chivenor & 12.8 & 7.7 & 17.8 \\
\hline 12 & 868 & Alice Holt Lodge & 12.4 & 7.3 & 17.5 \\
\hline 13 & 760 & Wye & 12.0 & 6.7 & 17.3 \\
\hline 14 & 1304 & Rodney Stoke & 12.1 & 7.0 & 17.2 \\
\hline 15 & 719 & Wisley & 12.2 & 7.0 & 17.3 \\
\hline 17 & 838 & Bracknell & 12.1 & 6.9 & 17.4 \\
\hline 18 & 830 & Reading University & 12.2 & 7.2 & 17.2 \\
\hline 20 & 697 & St James Park & 13.0 & 7.4 & 18.7 \\
\hline 22 & 825 & Wallingford & 11.9 & 7.4 & 16.4 \\
\hline 23 & 613 & Benson & 12.0 & 7.0 & 17.0 \\
\hline 24 & 609 & Shirburn & 12.3 & 6.6 & 18.0 \\
\hline 27 & 606 & Oxford & 12.4 & 6.5 & 18.3 \\
\hline 28 & 471 & Rothamsted & 12.0 & 6.7 & 17.4 \\
\hline 31 & 458 & Woburn & 11.2 & 6.7 & 15.7 \\
\hline 32 & 596 & Wellesbourne & 11.7 & 5.6 & 17.8 \\
\hline 33 & 454 & Cambridge Botanical Gardens & 11.7 & 6.2 & 17.2 \\
\hline 34 & 461 & Bedford & 11.7 & 6.9 & 16.4 \\
\hline 35 & 578 & Northampton, Moulton Park & 12.4 & 7.1 & 17.8 \\
\hline 36 & 435 & Brooms Barn & 12.3 & 6.2 & 18.4 \\
\hline 37 & 445 & Westleton & 11.9 & 5.2 & 18.5 \\
\hline 39 & 595 & Church Lawford & 12.0 & 6.1 & 17.9 \\
\hline 40 & 24102 & Coventry, Coundon & 12.0 & 6.3 & 17.7 \\
\hline 41 & 663 & Halesowen & 11.7 & 6.9 & 16.5 \\
\hline 42 & 19187 & Coleshill & 11.6 & 6.3 & 17.0 \\
\hline 43 & 413 & Santon Downham & 11.6 & 6.0 & 17.3 \\
\hline 44 & 638 & Preston Montford & 11.6 & 5.8 & 17.5 \\
\hline 47 & 392 & Kirton Horticulture & 10.8 & 5.5 & 16.1 \\
\hline 48 & 421 & Weybourne & 11.3 & 5.4 & 17.3 \\
\hline 49 & 622 & Keele & 11.6 & 6.6 & 16.5 \\
\hline 51 & 539 & Buxton & 11.8 & 6.2 & 17.4 \\
\hline 52 & 525 & Sheffield & 12.0 & 6.4 & 17.6 \\
\hline 53 & 19204 & Gringley-on-the-hill & 11.2 & 6.0 & 16.4 \\
\hline 55 & 516 & Bradford & 11.7 & 6.4 & 17.0 \\
\hline 56 & 535 & Cawood & 11.1 & 4.7 & 17.5 \\
\hline 57 & 1112 & Myerscough & 11.9 & 5.7 & 18.0 \\
\hline 59 & 1105 & Hazelrigg & 11.1 & 6.6 & 15.7 \\
\hline 62 & 1083 & Shap & 10.6 & 5.5 & 15.8 \\
\hline 65 & 1074 & Warcop Range & 10.8 & 5.8 & 15.9 \\
\hline 66 & 1060 & Keswick & 10.8 & 5.7 & 15.9 \\
\hline 67 & 17182 & Copley & 11.2 & 6.1 & 16.3 \\
\hline 71 & 326 & Durham & 11.5 & 6.1 & 16.9 \\
\hline 72 & 1066 & Drumburgh & 10.8 & 6.1 & 15.5 \\
\hline 73 & 1070 & Carlisle & 10.7 & 5.5 & 15.9 \\
\hline SCOTLAND 77 & 1023 & Eskdalemuir & 11.3 & 6.6 & 16.0 \\
\hline 78 & 968 & Paisley & 11.3 & 6.4 & 16.1 \\
\hline 79 & 24125 & Glasgow Bishopton & 10.8 & 5.8 & 15.8 \\
\hline 80 & 19260 & Edinburgh Gogarbank & 10.3 & 5.5 & 15.1 \\
\hline
\end{tabular}




\begin{tabular}{|c|c|c|c|c|c|}
\hline 83 & 212 & Strathallan airfield & 9.9 & 4.5 & 15.4 \\
\hline 84 & 235 & Leuchars & 9.9 & 5.1 & 14.8 \\
\hline 85 & 181 & Mylnefield & 9.9 & 5.5 & 14.3 \\
\hline 86 & 214 & Faskally & 10.4 & 4.6 & 16.2 \\
\hline 87 & 177 & Inverbervie No 2 & 10.5 & 5.8 & 15.2 \\
\hline 88 & 17310 & Fettercairn, Glensaugh No 2 & 9.8 & 4.7 & 14.8 \\
\hline 89 & 105 & Tulloch Bridge & 10.5 & 4.7 & 16.2 \\
\hline 90 & 147 & Braemar & 10.4 & 5.3 & 15.5 \\
\hline 91 & 150 & Aboyne No 2 & 9.9 & 4.6 & 15.2 \\
\hline 92 & 160 & Craibstone & 9.8 & 4.7 & 14.9 \\
\hline 93 & 161 & Dyce & 9.7 & 5.2 & 14.2 \\
\hline 94 & 113 & Aviemore & 9.8 & 4.5 & 15.2 \\
\hline 95 & 19172 & Skye: Lusa & 9.7 & 5.2 & 14.2 \\
\hline 96 & 18903 & South Uist range & 10.0 & 5.6 & 14.3 \\
\hline 97 & 132 & Kinloss & 9.3 & 4.8 & 13.9 \\
\hline 98 & 79 & Tain Range & 9.0 & 4.7 & 13.3 \\
\hline 99 & 52 & Aultbea No 2 & 9.9 & 5.0 & 14.8 \\
\hline 100 & 54 & Stornoway Airport & 9.6 & 5.2 & 14.1 \\
\hline 101 & 44 & Altnaharra No 2 & 9.4 & 4.7 & 14.1 \\
\hline 103 & 23 & Kirkwall & 9.1 & 4.9 & 13.4 \\
\hline 104 & 3 & Fair Isle & 9.2 & 5.8 & 12.7 \\
\hline 105 & 9 & Lerwick & 8.8 & 5.5 & 12.1 \\
\hline WALES & 1256 & Penmaen & 12.9 & 7.5 & 18.2 \\
\hline 30 & 1223 & Whitechurch & 12.1 & 8.0 & 16.2 \\
\hline 38 & 1209 & Trawsgoed & 12.1 & 7.3 & 16.9 \\
\hline 45 & 1161 & Aberdaron & 12.3 & 7.6 & 17.0 \\
\hline 46 & 1180 & Bala & 12.0 & 6.5 & 17.6 \\
\hline 50 & 1154 & Loggerheads & 11.8 & 6.7 & 16.9 \\
\hline N. IRELAND 60 & 1502 & Murlough & 11.0 & 6.3 & 15.7 \\
\hline 61 & 1509 & Magherally & 11.2 & 7.0 & 15.5 \\
\hline 63 & 1568 & St Angelo & 11.3 & 6.0 & 16.7 \\
\hline 64 & 1532 & Annaghmore & 11.4 & 7.3 & 15.5 \\
\hline 68 & 1517 & Ballywatticock & 10.8 & 6.7 & 15.0 \\
\hline 70 & 1523 & Helens Bay & 10.7 & 6.3 & 15.1 \\
\hline 76 & 1437 & Coleraine University & 10.5 & 6.5 & 14.5 \\
\hline
\end{tabular}

Table 1 
Table 2

\begin{tabular}{|c|c|c|c|c|c|c|}
\hline \multicolumn{2}{|c|}{$\begin{array}{l}\text { Urban mean temp. } \\
\left({ }^{\circ} \mathrm{C}\right)\end{array}$} & \multicolumn{2}{|c|}{$\begin{array}{l}\text { Rural mean temp. } \\
\left({ }^{\circ} \mathrm{C}\right)\end{array}$} & \multirow{2}{*}{$\begin{array}{l}\begin{array}{l}\text { Elevation } \\
\text { diff. (m) }\end{array} \\
17\end{array}$} & \multirow{2}{*}{$\begin{array}{l}\begin{array}{c}\text { Elevation corrected } \\
\text { rural mean temp. }\left({ }^{\circ} \mathrm{C}\right)\end{array} \\
11.5\end{array}$} & \multirow{2}{*}{$\begin{array}{l}\text { UHI effect at urban } \\
\text { location }\left({ }^{\circ} \mathrm{C}\right)\end{array}$} \\
\hline Bournemouth & 12.5 & Hurn & 11.6 & & & \\
\hline Reading & 11.7 & Bracknell & 11.7 & -8 & 11.7 & 0.0 \\
\hline Oxford & 12.0 & Benson & 11.6 & -4 & 11.6 & 0.4 \\
\hline Cambridge & 11.6 & $\begin{array}{l}\text { Brooms } \\
\text { Barn }\end{array}$ & 11.8 & -63 & 12.2 & -0.6 \\
\hline Northampton & 11.6 & Bedford & 11.1 & 42 & 10.8 & 0.8 \\
\hline Coventry & 11.2 & Coleshill & 11.0 & 12 & 10.9 & 0.3 \\
\hline Sheffield & 11.1 & $\begin{array}{l}\text { Gringley-on- } \\
\text { the-Hill }\end{array}$ & 10.8 & 63 & 10.4 & 0.7 \\
\hline Bradford & 10.8 & Cawood & 11.2 & 128 & 10.4 & 0.4 \\
\hline Durham & 10.8 & Copley & 9.6 & -151 & 10.5 & 0.3 \\
\hline Paisley & 11.1 & $\begin{array}{l}\text { Glasgow } \\
\text { Bishopton }\end{array}$ & 10.4 & -27 & 10.6 & 0.5 \\
\hline
\end{tabular}


Table 3

\begin{tabular}{|l|l|l|l|c|c|l|l|}
\hline \multicolumn{2}{|l|}{ Urban seasonal temp. $\left({ }^{\circ} \mathrm{C}\right)$} & \multicolumn{2}{|l|}{$\begin{array}{l}\text { Rural corrected seasonal } \\
\text { temp. }\left({ }^{\circ} \mathrm{C}\right)\end{array}$} & \multicolumn{2}{l|}{$\begin{array}{l}\text { Seasonal UHI effect at } \\
\text { urban location }\left({ }^{\circ} \mathrm{C}\right)\end{array}$} \\
\hline Met station & $\mathrm{S}_{\min }$ & $\mathrm{S}_{\max }$ & Met station & $\mathrm{S}_{\min }$ & $\mathrm{S}_{\max }$ & $\mathrm{S}_{\min }$ & $\mathrm{S}_{\max }$ \\
\hline Bournemouth & 7.0 & 18.1 & Hurn & 6.3 & 16.6 & 0.7 & 1.5 \\
\hline Reading & 6.8 & 16.8 & Bracknell & 6.4 & 17.0 & 0.4 & -0.2 \\
\hline Oxford & 6.1 & 17.9 & Benson & 6.6 & 16.6 & -0.5 & 1.3 \\
\hline Cambridge & 6.1 & 17.1 & Brooms Barn & 6.1 & 18.3 & 0.0 & -1.2 \\
\hline Northampton & 6.3 & 17.0 & Bedford & 6.1 & 15.6 & 0.2 & 1.4 \\
\hline Coventry & 5.5 & 17.0 & Coleshill & 5.6 & 16.2 & -0.1 & 0.8 \\
\hline Sheffield & 5.5 & 16.8 & $\begin{array}{l}\text { Gringley-on- } \\
\text { the-Hill }\end{array}$ & 5.2 & 15.6 & 0.3 & 1.2 \\
\hline Bradford & 5.5 & 16.1 & Cawood & 4.3 & 16.5 & 1.2 & -0.4 \\
\hline Durham & 5.4 & 16.2 & Copley & 5.4 & 15.7 & 0.0 & 0.5 \\
\hline Paisley & 6.2 & 15.9 & $\begin{array}{l}\text { Glasgow } \\
\text { Bishopton }\end{array}$ & 5.6 & 15.6 & 0.6 & 0.3 \\
\hline
\end{tabular}


Table 4

\begin{tabular}{|l|l|l|l|}
\hline Met Office station & $\begin{array}{l}\text { Mean annual temp. at } \\
100 \mathrm{~cm} \text { depth }\left({ }^{\circ} \mathrm{C}\right)\end{array}$ & $\begin{array}{l}\text { Mean annual } \\
\text { air temp. }\left({ }^{\circ} \mathrm{C}\right)\end{array}$ & $\begin{array}{l}\text { Difference of soil to } \\
\text { air temp. }\left({ }^{\circ} \mathrm{C}\right)\end{array}$ \\
\hline Camborne & 12.2 & 11.1 & 1.1 \\
\hline Hurn & 11.6 & 10.7 & 0.9 \\
\hline Eastbourne & 12.9 & 11.7 & 1.2 \\
\hline Wallingford & 11.6 & 10.9 & 0.7 \\
\hline Oxford & 12.0 & 11.1 & 0.9 \\
\hline Cambridge & 11.6 & 10.8 & 0.8 \\
\hline Sheffield & 11.1 & 10.6 & 0.5 \\
\hline Durham & 10.8 & 9.6 & 1.2 \\
\hline Eskdalemuir & 9.8 & 7.8 & 2.0 \\
\hline Braemar & 8.2 & 7.3 & 0.9 \\
\hline Stornoway airport & 9.5 & 9.0 & 0.5 \\
\hline Lerwick & 8.3 & 7.8 & 0.5 \\
\hline
\end{tabular}




\begin{tabular}{|c|c|c|c|c|c|}
\hline $\operatorname{Rec}$ & src_id & Met Office Weather Station name & $\begin{array}{l}\text { Easting } \\
\text { (m) }\end{array}$ & $\begin{array}{l}\text { Northing } \\
\text { (m) }\end{array}$ & $\begin{array}{l}\text { Elevation } \\
\text { (m) }\end{array}$ \\
\hline 1 & 1395 & Camborne & 162700 & 40700 & 87 \\
\hline 2 & 877 & Isle of Wight, Ventnor & 455700 & 77300 & 60 \\
\hline 3 & 1326 & Swanage & 403016 & 79332 & 10 \\
\hline 4 & 843 & Bournemouth & 412500 & 92772 & 27 \\
\hline 5 & 842 & Hurn & 411644 & 97778 & 10 \\
\hline 6 & 808 & Eastbourne & 561100 & 98000 & 7 \\
\hline 7 & 16608 & Littlehampton, Toddington Lane & 503700 & 104100 & 3 \\
\hline 8 & 1383 & Dunkeswell Aerodrome & 312815 & 107480 & 252 \\
\hline 9 & 865 & Butser, Windmill Hill & 472000 & 116500 & 92 \\
\hline 10 & 1346 & Chivenor & 249600 & 134400 & 6 \\
\hline 11 & 7786 & Boyton & 395209 & 140259 & 87 \\
\hline 12 & 868 & Alice Holt Lodge & 480500 & 142700 & 115 \\
\hline 13 & 760 & Wye & 605890 & 147010 & 56 \\
\hline 14 & 1304 & Rodney Stoke & 348849 & 150155 & 40 \\
\hline 15 & 719 & Wisley & 506300 & 157900 & 38 \\
\hline 16 & 1311 & Bath & 375131 & 163725 & 114 \\
\hline 17 & 838 & Bracknell & 484600 & 166400 & 74 \\
\hline 18 & 830 & Reading University, Whiteknights No 3 & 473900 & 171900 & 66 \\
\hline 19 & 723 & Kew & 518680 & 177380 & 6 \\
\hline 20 & 697 & St James' Park, London & 529800 & 180000 & 5 \\
\hline 21 & 1256 & Penmaen & 253100 & 188800 & 87 \\
\hline 22 & 825 & Wallingford & 461800 & 189800 & 48 \\
\hline 23 & 613 & Benson & 462500 & 191669 & 67 \\
\hline 24 & 609 & Shirburn & 469500 & 197100 & 108 \\
\hline 25 & 469 & Aldenham School & 515741 & 197284 & 91 \\
\hline 26 & 688 & Cirencester & 400300 & 201100 & 133 \\
\hline 27 & 606 & Oxford & 450900 & 207200 & 63 \\
\hline 28 & 471 & Rothamsted & 513156 & 213280 & 128 \\
\hline 29 & 1231 & Llandeilo & 259700 & 219900 & 80 \\
\hline 30 & 1223 & Whitechurch & 216200 & 235600 & 129 \\
\hline 31 & 458 & Woburn & 496400 & 236000 & 89 \\
\hline 32 & 596 & Wellesbourne & 427100 & 256500 & 47 \\
\hline 33 & 454 & Cambridge Botanical Gardens & 545600 & 257200 & 12 \\
\hline 34 & 461 & Bedford & 504900 & 259700 & 85 \\
\hline 35 & 578 & Northampton, Moulton Park & 476400 & 264500 & 127 \\
\hline 36 & 435 & Brooms Barn & 575300 & 265600 & 75 \\
\hline 37 & 445 & Westleton & 647300 & 267200 & 10 \\
\hline 38 & 1209 & Trawsgoed & 267395 & 273590 & 63 \\
\hline 39 & 595 & Church Lawford & 445600 & 273600 & 107 \\
\hline 40 & 24102 & Coventry, Coundon & 431600 & 280800 & 119 \\
\hline 41 & 663 & Halesowen & 394900 & 282200 & 153 \\
\hline 42 & 19187 & Coleshill & 421090 & 286940 & 96 \\
\hline 43 & 413 & Santon Downham & 581600 & 287900 & 6 \\
\hline 44 & 638 & Preston Montford & 343200 & 314400 & 71 \\
\hline 45 & 1161 & Aberdaron & 215200 & 324800 & 95 \\
\hline 46 & 1180 & Bala & 293500 & 335600 & 163 \\
\hline 47 & 392 & Kirton Horticulture & 529920 & 339450 & 4 \\
\hline 48 & 421 & Weybourne & 609900 & 343700 & 21 \\
\hline 49 & 622 & Keele & 381900 & 344600 & 179 \\
\hline 50 & 1154 & Loggerheads, Colomendy Centre & 320030 & 362160 & 210 \\
\hline 51 & 539 & Buxton & 405800 & 373400 & 307 \\
\hline 52 & 525 & Sheffield & 433930 & 387280 & 131 \\
\hline 53 & 19204 & Gringley-on-the-hill & 474260 & 390500 & 68 \\
\hline 54 & 369 & Hull & 508350 & 430130 & 2 \\
\hline 55 & 516 & Bradford & 414900 & 435200 & 134 \\
\hline
\end{tabular}




\begin{tabular}{|c|c|c|c|c|c|}
\hline 56 & 535 & Cawood & 456100 & 437200 & 6 \\
\hline 57 & 1112 & Myerscough & 349500 & 440000 & 14 \\
\hline 58 & 370 & Leconfield & 502545 & 443169 & 7 \\
\hline 59 & 1105 & Hazelrigg & 349300 & 457820 & 95 \\
\hline 60 & 1502 & Murlough & 150486 & 490209 & 12 \\
\hline 61 & 1509 & Magherally & 127475 & 504236 & 97 \\
\hline 62 & 1083 & Shap & 355700 & 512000 & 255 \\
\hline 63 & 1568 & St Angelo & 33740 & 514703 & 47 \\
\hline 64 & 1532 & Annaghmore & 101838 & 516887 & 27 \\
\hline 65 & 1074 & Warcop Range & 373300 & 519700 & 227 \\
\hline 66 & 1060 & Keswick & 325300 & 524900 & 81 \\
\hline 67 & 17182 & Copley & 408500 & 525400 & 253 \\
\hline 68 & 1517 & Ballywatticock & 163835 & 525962 & 6 \\
\hline 69 & 1073 & Newton Rigg & 349300 & 530800 & 169 \\
\hline 70 & 1523 & Helens Bay & 158462 & 536950 & 43 \\
\hline 71 & 326 & Durham & 426700 & 541500 & 102 \\
\hline 72 & 1066 & Drumburgh & 325900 & 560200 & 7 \\
\hline 73 & 1070 & Carlisle & 338300 & 560300 & 28 \\
\hline 74 & 24790 & Drumlamford House & 228800 & 576900 & 132 \\
\hline 75 & 310 & Morpeth, Cockle Park & 420000 & 591200 & 95 \\
\hline 76 & 1437 & Coleraine University & 102081 & 594462 & 23 \\
\hline 77 & 1023 & Eskdalemuir & 323500 & 602600 & 242 \\
\hline 78 & 968 & Paisley & 247895 & 664032 & 32 \\
\hline 79 & 24125 & Glasgow Bishopton & 241788 & 671073 & 59 \\
\hline 80 & 19260 & Edinburgh Gogarbank & 316100 & 671400 & 57 \\
\hline 81 & 247 & Edinburgh, East Craigs & 318500 & 673500 & 61 \\
\hline 82 & 253 & Edinburgh Botanic Gardens & 324500 & 675500 & 26 \\
\hline 83 & 212 & Strathallan airfield & 293100 & 716200 & 35 \\
\hline 84 & 235 & Leuchars & 346800 & 720900 & 10 \\
\hline 85 & 181 & Mylnefield & 333900 & 730100 & 31 \\
\hline 86 & 214 & Faskally & 291800 & 759900 & 94 \\
\hline 87 & 177 & Inverbervie No 2 & 383884 & 773425 & 134 \\
\hline 88 & 17310 & Fettercairn, Glensaugh No 2 & 366900 & 778200 & 171 \\
\hline 89 & 105 & Tulloch Bridge & 235030 & 778298 & 237 \\
\hline 90 & 147 & Braemar & 315200 & 791400 & 339 \\
\hline 91 & 150 & Aboyne No 2 & 349300 & 798700 & 140 \\
\hline 92 & 160 & Craibstone & 387100 & 810700 & 102 \\
\hline 93 & 161 & Dyce & 387810 & 812800 & 65 \\
\hline 94 & 113 & Aviemore & 289652 & 814315 & 228 \\
\hline 95 & 19172 & Skye: Lusa & 170593 & 824888 & 18 \\
\hline 96 & 18903 & South Uist range & 76312 & 842502 & 4 \\
\hline 97 & 132 & Kinloss & 306774 & 862804 & 5 \\
\hline 98 & 79 & Tain Range & 283272 & 882720 & 4 \\
\hline 99 & 52 & Aultbea No 2 & 184575 & 891274 & 11 \\
\hline 100 & 54 & Stornoway Airport & 146443 & 933104 & 15 \\
\hline 101 & 44 & Altnaharra No 2 & 256908 & 935830 & 81 \\
\hline 102 & 32 & Wick Airport & 336490 & 952230 & 36 \\
\hline 103 & 23 & Kirkwall & 348236 & 1007709 & 26 \\
\hline 104 & 3 & Fair Isle & 421046 & 1071185 & 57 \\
\hline 105 & 9 & Lerwick & 445392 & 1139664 & 82 \\
\hline 106 & 12 & Baltasound No 2 & 462488 & 1207786 & 15 \\
\hline
\end{tabular}

Appendix Table A1 


\begin{tabular}{|c|c|c|c|c|c|c|c|c|}
\hline Rec & Src_id & $\begin{array}{c}\text { Abbreviated station } \\
\text { name }\end{array}$ & $\begin{array}{c}\text { Time period \& } \\
\text { Depth }(\mathbf{c m})\end{array}$ & Mean $\left({ }^{\circ} \mathrm{C}\right)$ & $\begin{array}{l}\mathrm{S}_{\min } \\
\left({ }^{\circ} \mathrm{C}\right)\end{array}$ & $\begin{array}{l}\mathrm{S}_{\max } \\
\left({ }^{\circ} \mathrm{C}\right)\end{array}$ & $\begin{array}{l}\mathrm{D}_{\min } \\
\left({ }^{\circ} \mathrm{C}\right)\end{array}$ & $\begin{array}{l}D_{\max } \\
\left({ }^{\circ} \mathrm{C}\right)\end{array}$ \\
\hline \multirow{2}{*}{1} & \multirow{2}{*}{1395} & \multirow{2}{*}{ Camborne } & $2000-2010(30)$ & 12.1 & 6.7 & 17.5 & 3.0 & 20.0 \\
\hline & & & $2000-2010(100)$ & 12.2 & 7.4 & 16.9 & 5.5 & 18.3 \\
\hline 2 & 877 & Isle of Wight & $2000-2003(30)$ & 12.7 & 5.9 & 19.4 & 3.0 & 22.9 \\
\hline 3 & 1326 & Swanage & $2000-2003(100)$ & 12.6 & 8.1 & 17.2 & 7.2 & 18.7 \\
\hline \multirow{2}{*}{4} & \multirow{2}{*}{843} & \multirow{2}{*}{ Bournemouth } & $2000-2003(30)$ & 12.4 & 5.6 & 19.3 & 2.5 & 22.8 \\
\hline & & & $2000-2003(100)$ & 12.5 & 7.0 & 18.1 & 5.7 & 20.0 \\
\hline \multirow{2}{*}{5} & \multirow{2}{*}{842} & \multirow{2}{*}{ Hurn } & $2000-2010(30)$ & 11.9 & 5.1 & 18.7 & 1.6 & 22.8 \\
\hline & & & $2000-2010(100)$ & 11.6 & 6.3 & 16.9 & 4.1 & 19.2 \\
\hline \multirow{2}{*}{6} & \multirow{2}{*}{808} & \multirow{2}{*}{ Eastbourne } & $2000-2004(30)$ & 12.5 & 6.0 & 19.1 & 2.7 & 22.8 \\
\hline & & & $2000-2004(100)$ & 12.9 & 7.8 & 18.0 & 6.7 & 19.7 \\
\hline \multirow{2}{*}{7} & \multirow{2}{*}{16608} & \multirow{2}{*}{ Littlehampton } & $2000-2002(50)$ & 12.6 & 6 & 19.2 & 3.3 & 21.7 \\
\hline & & & $2000-2002(100)$ & 12.7 & 6.9 & 18.6 & 5.1 & 20.3 \\
\hline 8 & 1383 & & $2001-2010(30)$ & 11.5 & 4.5 & 18.5 & -0.1 & 21.9 \\
\hline 8 & 1383 & |Dunkeswell & $2001-2010(100)$ & 11.2 & 5.9 & 16.5 & 2.2 & 18.8 \\
\hline & & & $2000-2004(50)$ & 11.4 & 5.4 & 17.4 & 3 & 19.4 \\
\hline 9 & 865 & Butser & $2000-2004(100)$ & 11.2 & 6.2 & 16.2 & 4.5 & 17.0 \\
\hline & & & $2001-2010(30)$ & 12.4 & 6.3 & 18.5 & 2.0 & 21.2 \\
\hline 10 & 1346 & Chivenor & $2001-2010(100)$ & 12.7 & 7.7 & 17.8 & 5.8 & 19.5 \\
\hline 11 & 7786 & Boyton & $2000-2004(30)$ & 11.4 & 5.4 & 17.3 & 2.6 & 20.8 \\
\hline & & & $2000-2006(50)$ & 11.7 & 5.4 & 18.1 & 3.2 & 20.0 \\
\hline 12 & 868 & Alice Holt Lodge & $2000-2006(100)$ & 11.7 & 6.6 & 16.8 & 5.5 & 17.5 \\
\hline & & & $2000-2004(50)$ & 11.7 & 5.5 & 17.8 & 3 & 20.7 \\
\hline 13 & 160 & Wye & $2000-2004(100)$ & 11.6 & 6.3 & 16.9 & 5.2 & 18.9 \\
\hline & & & $2000-2004(50)$ & 12.0 & 5.8 & 18.3 & 4.0 & 21.5 \\
\hline 14 & 1304 & Rodney Stoke & $2000-2004(100)$ & 11.9 & 6.8 & 17.0 & 6.0 & 18.5 \\
\hline 15 & & & $2000-2000(50)$ & 12.0 & 5.9 & 18.2 & 3.3 & 19.3 \\
\hline 15 & 719 & Wisley & $2000-2000(100)$ & 11.9 & 6.8 & 17.1 & 5.6 & 17.7 \\
\hline 16 & 1311 & Bath & $2000-2004(30)$ & 12.2 & 5.6 & 18.9 & 3.0 & 23.0 \\
\hline 17 & 838 & Bracknell & $2000-2002(100)$ & 11.7 & 6.4 & 16.9 & 4.8 & 17.9 \\
\hline 10 & & & $2000-2006(50)$ & 11.8 & 5.9 & 17.7 & 3.4 & 20.5 \\
\hline 18 & 830 & Reading Univ. & $2000-2006(100)$ & 11.8 & 6.8 & 16.8 & 5.6 & 18.2 \\
\hline 19 & 723 & Kew & $2000-2004(30)$ & 11.9 & 4.7 & 19.0 & 2.1 & 23.6 \\
\hline & & & $2000-2004(30)$ & 13.6 & 6.5 & 20.7 & 4.3 & 24.0 \\
\hline 20 & 697 & St James Park & $2000-2004(100)$ & 13.0 & 7.4 & 18.6 & 6.3 & 21.6 \\
\hline 22 & 825 & & $2000-2006(50)$ & 11.7 & 6.2 & 17.2 & 4.0 & 20.2 \\
\hline 22 & 825 & |Wallingtord & $2000-2006(100)$ & 11.6 & 7.1 & 16.1 & 6.0 & 17.8 \\
\hline 22 & 612 & Roncon & $2007-2008(30)$ & 11.4 & 5.5 & 17.4 & 3.7 & 18.9 \\
\hline 23 & 613 & Benson & $2007-2008(100)$ & 11.6 & 6.6 & 16.6 & 5.9 & 17.4 \\
\hline 21 & 600 & Chirburn & $2000-2004(30)$ & 11.4 & 4.4 & 18.5 & 1.5 & 21.7 \\
\hline 24 & 609 & Shirburn & $2000-2004(100)$ & 11.6 & 5.9 & 17.3 & 4.7 & 19.1 \\
\hline 25 & 469 & Aldenham School & $2000-2004(30)$ & 10.8 & 4.2 & 17.4 & 1.5 & 20.5 \\
\hline 26 & 600 & Cironentor & $2000-2004(30)$ & 11.1 & 4.2 & 17.9 & 0.2 & 22.0 \\
\hline 26 & 688 & Cirencester & $2000-2004(50)$ & 11.3 & 4.8 & 17.9 & 2.6 & 21.3 \\
\hline 27 & 606 & Ooxford & $2000-2004(30)$ & 11.8 & 4.4 & 19.3 & 4.3 & 24.0 \\
\hline 27 & 606 & |Oxford & $2000-2004(100)$ & 12.0 & 6.1 & 17.9 & 6.3 & 21.6 \\
\hline 20 & 171 & Dothomatod & $2001-2010(30)$ & 11.1 & 4.1 & 18.0 & 1.8 & 21.7 \\
\hline 28 & $4 / 1$ & |Rothamsted & $2001-2010(100)$ & 11.2 & 5.8 & 16.6 & 4.2 & 18.0 \\
\hline 21 & & Worburn & $2001-2003(30)$ & 10.8 & 4.6 & 17.0 & 2.0 & 19.3 \\
\hline 31 & 458 & Woburn & $2001-2003(100)$ & 10.6 & 6.1 & 15.1 & 5.2 & 16.0 \\
\hline 32 & & & $2000-2004(50)$ & 11.3 & 4.5 & 18.1 & 2.2 & 21.3 \\
\hline 32 & 596 & Wellesbourne & $2000-2004(100)$ & 11.4 & 5.3 & 17.5 & 3.8 & 20.0 \\
\hline & & & $2000-2004(30)$ & 11.4 & 4.4 & 18.4 & 1.8 & 21.8 \\
\hline 33 & 454 & Cambridge & $2000-2004(100)$ & 11.6 & 6.1 & 17.1 & 4.9 & 18.9 \\
\hline 21 & & Pedford & $2000-2008(30)$ & 11.3 & 5.0 & 17.6 & 2.9 & 21.3 \\
\hline 34 & 461 & Bedtord & $2000-2008(100)$ & 11.1 & 6.4 & 15.9 & 5.3 & 17.7 \\
\hline & & & $2000-2006(50)$ & 11.8 & 5.2 & 18.5 & 3.5 & 21.2 \\
\hline 35 & 578 & Northampton & $2000-2006(100)$ & 11.6 & 6.3 & 17.0 & 5.1 & 18.8 \\
\hline 36 & 435 & Brooms Barn & $2000-2006(50)$ & 11.8 & 4.8 & 18.9 & 2.7 & 21.3 \\
\hline
\end{tabular}




\begin{tabular}{|c|c|c|c|c|c|c|c|c|}
\hline & & & $2000-2006(100)$ & 11.8 & 5.7 & 17.9 & 4.7 & 19.7 \\
\hline \multirow{2}{*}{37} & \multirow{2}{*}{445} & \multirow{2}{*}{ Westleton } & $2000-2004(50)$ & 11.8 & 4.3 & 19.2 & 1.7 & 23.0 \\
\hline & & & $2000-2004(100)$ & 11.8 & 5.1 & 18.5 & 3.7 & 21.0 \\
\hline \multirow{2}{*}{39} & \multirow{2}{*}{595} & \multirow{2}{*}{ Church Lawford } & $2000-2010(30)$ & 11.3 & 4.5 & 18.1 & 2.0 & 21.5 \\
\hline & & & $2000-2010(100)$ & 11.3 & 5.4 & 17.2 & 3.4 & 19.4 \\
\hline \multirow{2}{*}{40} & \multirow{2}{*}{24102} & \multirow{2}{*}{ Coventry } & $2000-2010(30)$ & 11.0 & 3.9 & 18.1 & 1.4 & 23.1 \\
\hline & & & $2000-2010(100)$ & 11.2 & 5.5 & 17.0 & 4.4 & 19.4 \\
\hline \multirow{2}{*}{41} & \multirow{2}{*}{663} & \multirow{2}{*}{ Halesowen } & $2000-2003(50)$ & 10.7 & 4.8 & 16.7 & 3.2 & 19.0 \\
\hline & & & $2000-2003(100)$ & 10.7 & 6.0 & 15.5 & 5.0 & 17.0 \\
\hline \multirow{2}{*}{42} & \multirow{2}{*}{19187} & \multirow{2}{*}{ Coleshill } & $2000-2010(30)$ & 11.1 & 4.7 & 17.4 & 2.4 & 21.1 \\
\hline & & & $2000-2010(100)$ & 11.0 & 5.7 & 16.3 & 4.3 & 18.5 \\
\hline \multirow{2}{*}{43} & \multirow{2}{*}{413} & \multirow{2}{*}{ Santon Downham } & $2000-2004(30)$ & 11.4 & 4.3 & 18.4 & 1.8 & 21.6 \\
\hline & & & $2000-2004(100)$ & 11.6 & 5.9 & 17.3 & 4.7 & 19.1 \\
\hline & & & $2001-2006(30)$ & 11.1 & 4.2 & 18.0 & 1.2 & 21.3 \\
\hline 44 & 038 & preston iviontiora & $2001-2006$ (100) & 11.2 & 5.3 & 17.0 & 3.5 & 18.8 \\
\hline 47 & 392 & Kirton Horticulture & $2000-2004(50)$ & 10.9 & 4.6 & 17.2 & 2.8 & 21.1 \\
\hline $4 t$ & 392 & Kirton norticuiture & $2000-2004$ (100) & 10.8 & 5.5 & 16.1 & 4.6 & 18.4 \\
\hline & & & $2000-2003(30)$ & 10.8 & 3.7 & 17.9 & -1.5 & 21.4 \\
\hline 48 & 421 & veybourne & $2000-2003$ (100) & 11.2 & 5.2 & 17.1 & 3.8 & 19.4 \\
\hline & & & $2001-2005(50)$ & 10.6 & 4.5 & 16.6 & 3.0 & 18.4 \\
\hline 49 & 622 & Keele & $2001-2005$ (100) & 10.4 & 5.5 & 15.3 & 4.8 & 16.3 \\
\hline 51 & 539 & & $2000-2006(50)$ & 10.0 & 3.4 & 16.6 & 1.5 & 19.7 \\
\hline 31 & 539 & Buxton & $2000-2006$ (100) & 9.8 & 4.2 & 15.4 & 2.9 & 17.9 \\
\hline & & & $2002-2004(30)$ & 11.0 & 4.1 & 18.0 & 2.1 & 20.3 \\
\hline 52 & $5<5$ & snemiela & $2002-2004(100)$ & 11.1 & 5.5 & 16.8 & 4.4 & 18.1 \\
\hline & & & $2002-2004(30)$ & 10.8 & 4.6 & 17.0 & 2.1 & 19.5 \\
\hline 53 & 19204 & Gringley-on-the-nill & $2002-2004(100)$ & 10.8 & 5.6 & 16.0 & 4.4 & 17.2 \\
\hline 54 & 369 & Hull & $2008-2009(30)$ & 10.8 & 3.6 & 18.1 & 1.0 & 20.0 \\
\hline 55 & 516 & Rradford & $2004-2004(30)$ & 10.6 & 4.2 & 17.0 & 2.9 & 18.6 \\
\hline 30 & 510 & DTauioru & 2004-2004 (100) & 10.8 & 5.5 & 16.1 & 5.1 & 17.0 \\
\hline & & & $2001-2004(50)$ & 11.0 & 3.8 & 18.2 & 1.4 & 20.9 \\
\hline 56 & 535 & cawood & 2001-2004 (100) & 11.0 & 4.6 & 17.4 & 3.3 & 19.5 \\
\hline & & & $2001-2004(50)$ & 11.9 & 4.6 & 19.2 & 2.5 & 21.0 \\
\hline $5 /$ & 1112 & Myerscough & 2001-2004 (100) & 11.8 & 5.7 & 17.9 & 4.7 & 19.1 \\
\hline 58 & 370 & Leconfield & $2008-2009(30)$ & 10.8 & 4.2 & 17.5 & 2.1 & 19.6 \\
\hline & & & $2000-2006(50)$ & 10.4 & 4.8 & 16.0 & 2.2 & 18.5 \\
\hline 59 & 1105 & Hazelrıgg & $2000-2006$ (100) & 10.5 & 6.0 & 15.1 & 4.3 & 16.5 \\
\hline 62 & 1083 & Shan & $2005-2010(30)$ & 9.2 & 2.6 & 15.7 & 1.1 & 17.5 \\
\hline 02 & 1083 & smap & $2005-2010(100)$ & 9.0 & 3.8 & 14.1 & 2.7 & 14.9 \\
\hline & & & $2000-2010(30)$ & 9.5 & 3.4 & 15.6 & 1.2 & 18.0 \\
\hline 65 & $10 / 4$ & Wvarcop Range & $2000-2010(100)$ & 9.4 & 4.3 & 14.4 & 1.5 & 16.3 \\
\hline 66 & 1060 & Keswick & $2000-2001(30)$ & 11.0 & 4.1 & 17.9 & 2.0 & 19.5 \\
\hline 00 & 1000 & neswick & $2000-2001$ (100) & 10.3 & 5.2 & 15.4 & 4.5 & 16.3 \\
\hline & & & $2000-2004(30)$ & 9.7 & 3.2 & 16.1 & 1.9 & 19.2 \\
\hline $6 /$ & $1 / 182$ & copley & $2000-2004(100)$ & 9.6 & 4.4 & 14.7 & 3.4 & 16.5 \\
\hline & & & $2000-2006(30)$ & 10.0 & 3.4 & 16.7 & 0.9 & 20.4 \\
\hline 69 & $10 / 3$ & Newton Rigg & $2000-2006(50)$ & 10.2 & 3.9 & 16.5 & 1.8 & 20.0 \\
\hline 71 & 326 & Durham & $2000-2004(30)$ & 10.4 & 3.5 & 17.4 & 1.4 & 20.3 \\
\hline 71 & $3<0$ & Durmant & $2000-2004(100)$ & 10.8 & 5.4 & 16.2 & 4.7 & 17.5 \\
\hline 72 & 1066 & Drumburgh & $2006-2010(100)$ & 10.8 & 6.1 & 15.5 & 4.9 & 15.9 \\
\hline 73 & 1070 & Carlisle & $2006-2010(100)$ & 10.5 & 5.3 & 15.8 & 3.9 & 17.5 \\
\hline & & & $2001-2006(30)$ & 9.51 & 3.4 & 15.6 & 1.4 & 18.4 \\
\hline 15 & 310 & IVorpeth & $2001-2006$ (50) & 9.6 & 3.9 & 15.3 & 1.9 & 17.8 \\
\hline
\end{tabular}

Appendix Table A2 


\begin{tabular}{|c|c|c|c|c|c|c|c|c|}
\hline Rec & Src_id & $\begin{array}{l}\text { Abbreviated station } \\
\text { name }\end{array}$ & $\begin{array}{l}\text { Time period \& } \\
\text { Depth }(\mathrm{cm})\end{array}$ & Mean $\left({ }^{\circ} \mathrm{C}\right)$ & $\begin{array}{l}\mathrm{S}_{\min } \\
\left({ }^{\circ} \mathrm{C}\right)\end{array}$ & $\begin{array}{l}\mathrm{S}_{\max } \\
\left({ }^{\circ} \mathrm{C}\right)\end{array}$ & $\begin{array}{l}D_{\min } \\
\left({ }^{\circ} \mathrm{C}\right)\end{array}$ & $\begin{array}{l}D_{\max } \\
\left({ }^{\circ} \mathrm{C}\right)\end{array}$ \\
\hline 74 & 24790 & Drumlamford House & $2000-2004(30)$ & 9.9 & 4.2 & 15.7 & 2.1 & 18.4 \\
\hline \multirow{2}{*}{77} & \multirow{2}{*}{1023} & \multirow{2}{*}{ Eskdalemuir } & $2000-2010(30)$ & 9.9 & 3.9 & 15.9 & 2.3 & 18.0 \\
\hline & & & $2000-2010(100)$ & 9.8 & 5.0 & 14.5 & 3.7 & 15.9 \\
\hline \multirow{2}{*}{78} & \multirow{2}{*}{968} & \multirow{2}{*}{ Paisley } & $2000-2007(50)$ & 11.0 & 4.9 & 17.0 & 2.8 & 19.1 \\
\hline & & & $2000-2007(100)$ & 11.1 & 6.2 & 15.9 & 5.0 & 18.0 \\
\hline \multirow{2}{*}{79} & \multirow{2}{*}{24125} & \multirow{2}{*}{ Glasgow, Bishopton } & $2000-2007(30)$ & 10.5 & 4.0 & 17.1 & 1.4 & 19.9 \\
\hline & & & $2000-2007(100)$ & 10.4 & 5.5 & 15.4 & 4.1 & 16.7 \\
\hline \multirow{2}{*}{80} & \multirow{2}{*}{19260} & \multirow{2}{*}{ Edinburgh, Gogarbank } & $2000-2004(30)$ & 10.1 & 3.9 & 16.2 & 2.0 & 18.5 \\
\hline & & & $2000-2004(100)$ & 9.9 & 5.1 & 14.7 & 4.0 & 15.8 \\
\hline \multirow{2}{*}{81} & \multirow{2}{*}{247} & \multirow{2}{*}{ Edinburgh, East Craigs } & $2000-2004(30)$ & 9.7 & 3.3 & 16.2 & 0.7 & 19.1 \\
\hline & & & $2000-2004(50)$ & 10.0 & 4.0 & 15.9 & 2.0 & 18.2 \\
\hline 82 & 253 & Edinburgh, Botanic Gardens & $2000-2010(30)$ & 9.8 & 3.5 & 16.2 & 0.9 & 20.2 \\
\hline 83 & 212 & & $2000-2010(30)$ & 10.0 & 3.4 & 16.7 & 0.8 & 19.6 \\
\hline 83 & 212 & Strathallan alrtield & $2000-2010(100)$ & 9.7 & 4.2 & 15.1 & 2.4 & 16.5 \\
\hline & & & $2002-2010(30)$ & 9.8 & 4.1 & 15.5 & 1.4 & 17.8 \\
\hline 84 & 235 & Leuchars & $2002-2010(100)$ & 9.9 & 5.0 & 14.7 & 3.4 & 16.1 \\
\hline & & & $2004-2010(30)$ & 9.6 & 3.0 & 16.2 & 0.0 & 19.3 \\
\hline 85 & 181 & IMyinetield & $2004-2010(100)$ & 9.7 & 5.3 & 14.1 & $\begin{array}{l}3.7 \\
\end{array}$ & 15.5 \\
\hline 86 & 211 & Forolly & $2000-2009(30)$ & 9.8 & 2.1 & 17.5 & 0.5 & 20.6 \\
\hline 86 & 214 & Faskanly & $2000-2009(100)$ & 9.8 & 4.0 & 15.5 & 2.9 & 17.0 \\
\hline & & & $2003-2009(30)$ & 9.5 & 3.6 & 15.5 & 1.4 & 18.4 \\
\hline 81 & 176 & Inverbervie No 2 & $2003-2009(100)$ & 9.6 & 4.9 & 14.3 & 3.7 & 15.4 \\
\hline 89 & & Fottorcairn Sloncaugh No? & $2000-2004(30)$ & 8.7 & 1.9 & 15.4 & 0.5 & 17.9 \\
\hline 88 & 17310 & Fettercairn, Glensaugn ino 2 & $2000-2004(100)$ & 8.6 & 3.6 & 13.7 & 1.5 & 14.9 \\
\hline & & & $2001-2010(30)$ & 9.1 & 2.3 & 15.9 & 0.8 & 19.0 \\
\hline 89 & 105 & fulloch Briage & $2001-2010(100)$ & 8.9 & 3.1 & 14.7 & 1.8 & 16.4 \\
\hline & & & $2000-2004(50)$ & 8.2 & 2.3 & 14.1 & 1.3 & 15.9 \\
\hline 90 & 147 & Braemar & $2000-2004(100)$ & 8.2 & 3.1 & 13.3 & 2.2 & 14.6 \\
\hline & & & $2002-2008(30)$ & 9.2 & 2.7 & 15.7 & 1.8 & 17.7 \\
\hline 91 & 150 & Aboyne No 2 & $2002-2008(100)$ & 9.0 & 3.7 & 14.3 & 3.1 & 15.8 \\
\hline & & & $2000-2004(30)$ & 9.1 & 2.9 & 15.4 & 1.4 & 17.3 \\
\hline 92 & 160 & Craibstone & $2000-2004(100)$ & 9.1 & 4.0 & 14.2 & 3.0 & 15.4 \\
\hline & & & $2000-2010(30)$ & 9.3 & 3.4 & 15.3 & 1.6 & 18.4 \\
\hline 93 & 161 & Dyce & $2000-2010(100)$ & 9.3 & 4.7 & 13.8 & 3.4 & 14.8 \\
\hline & & & $2000-2010(30)$ & 8.4 & 1.7 & 15.2 & 0.3 & 17.5 \\
\hline 94 & 113 & Aviemore & $2000-2010(100)$ & 8.3 & 3.0 & 13.7 & 1.2 & 14.7 \\
\hline & 10172 & Ckyo & $2000-2010(30)$ & 9.8 & 4.0 & 15.6 & 1.4 & 18.5 \\
\hline 95 & $191 / 2$ & Skye & $2000-2010(100)$ & 9.6 & 5.1 & 14.1 & 3.5 & 15.7 \\
\hline & 10002 & & $2001-2006(30)$ & 10.1 & 4.7 & 15.4 & 2.0 & 18.4 \\
\hline 96 & 18903 & South UISt range & $2001-2006(100)$ & 10.0 & 5.6 & 14.3 & 3.9 & 16.1 \\
\hline 97 & 132 & Kinloce & $2000-2010(30)$ & 9.5 & 3.7 & 15.3 & 0.9 & 17.6 \\
\hline 97 & 132 & KInloss & $2000-2010(100)$ & 9.3 & 4.8 & 13.8 & 2.6 & 15.0 \\
\hline & 79 & Tain Range & $2000-2005(30)$ & 9.1 & 3.4 & 14.7 & 0.9 & 16.4 \\
\hline 98 & 19 & Tain Range & $2000-2005(100)$ & 9.0 & 4.7 & 13.3 & 2.8 & 14.3 \\
\hline & & & $2000-2010(30)$ & 9.8 & 3.4 & 16.1 & 0.0 & 19.7 \\
\hline 99 & 52 & Aultbea No 2 & $2000-2010(100)$ & 9.9 & 5.0 & 14.7 & 3.4 & 16.6 \\
\hline 100 & 54 & Stornoway Airnort & $2004-2010(30)$ & 9.7 & 4.2 & 15.2 & 1.5 & 18.0 \\
\hline 100 & 54 & Stornoway Airport & $2004-2010(100)$ & 9.5 & 5.1 & 14.0 & 3.7 & 14.7 \\
\hline & & & $2000-2010(30)$ & 8.9 & 3.0 & 14.8 & 1.1 & 18.5 \\
\hline 101 & 44 & Altnaharra No 2 & $2000-2010(100)$ & 8.9 & 4.2 & 13.6 & 2.9 & 15.6 \\
\hline 102 & 32 & Wick Airport & $2002-2010(30)$ & 8.4 & 3.3 & 13.4 & 1.5 & 16.5 \\
\hline 103 & & & $2003-2010(30)$ & 9.0 & 3.5 & 14.5 & 1.7 & 17.6 \\
\hline 103 & 23 & KIrkwall & $2003-2010(100)$ & 9.0 & 4.7 & 13.3 & 3.6 & 14.7 \\
\hline & & & $2000-2010(30)$ & 9.0 & 4.5 & 13.4 & 2.7 & 16.3 \\
\hline 104 & 3 & Fair Isle & $2000-2010(100)$ & 8.9 & 5.4 & 12.4 & 4.0 & 13.4 \\
\hline & & & $2000-2010(30)$ & 8.4 & 3.2 & 13.6 & 1.3 & 16.9 \\
\hline 105 & 9 & Lerwick & $2000-2010(100)$ & 8.3 & 5.0 & 11.6 & 4.0 & 13.1 \\
\hline 106 & 12 & Baltasound No 2 & $2002-2009(30)$ & 8.6 & 3.1 & 14.1 & 1.8 & 18.0 \\
\hline
\end{tabular}

Appendix Table A3 
Appendix Table A4

\begin{tabular}{|c|c|c|c|c|c|c|c|c|}
\hline $\operatorname{Rec}$ & Src_id & $\begin{array}{c}\text { Abbreviated station } \\
\text { name }\end{array}$ & $\begin{array}{l}\text { Time period \& } \\
\text { Depth }(\mathrm{cm})\end{array}$ & Mean $\left({ }^{\circ} \mathrm{C}\right)$ & $\begin{array}{l}\mathrm{S}_{\min } \\
\left({ }^{\circ} \mathrm{C}\right)\end{array}$ & $\begin{array}{l}\mathrm{S}_{\max } \\
\left({ }^{\circ} \mathrm{C}\right)\end{array}$ & $\begin{array}{l}\mathrm{D}_{\min } \\
\left({ }^{\circ} \mathrm{C}\right)\end{array}$ & $\begin{array}{l}D_{\max } \\
\left({ }^{\circ} \mathrm{C}\right)\end{array}$ \\
\hline \multirow{2}{*}{21} & \multirow{2}{*}{1256} & \multirow{2}{*}{ Penmaen } & $2000-2004(50)$ & 12.3 & 6.4 & 18.1 & 4.7 & 19.9 \\
\hline & & & $2000-2004(100)$ & 12.3 & 7.0 & 17.6 & 5.6 & 18.9 \\
\hline 29 & 1231 & Llandeilo & $2000-2004(30)$ & 11.4 & 5.7 & 17.1 & 3.2 & 19.5 \\
\hline \multirow{2}{*}{30} & \multirow{2}{*}{1223} & \multirow{2}{*}{ Whitechurch } & $2002-2004(50)$ & 11.5 & 6.2 & 16.8 & 3.6 & 17.8 \\
\hline & & & 2002-2004 (100) & 11.2 & 7.2 & 15.3 & 5.6 & 16.1 \\
\hline \multirow{2}{*}{38} & \multirow{2}{*}{1209} & \multirow{2}{*}{ Trawsgoed } & $2000-2004(30)$ & 11.8 & 5.7 & 18.0 & 2.7 & 20.5 \\
\hline & & & $2000-2004(100)$ & 11.7 & 6.9 & 16.5 & 5.8 & 17.5 \\
\hline \multirow{2}{*}{45} & \multirow{2}{*}{1161} & \multirow{2}{*}{ Aberdaron } & $2000-2007(30)$ & 11.7 & 6.1 & 17.2 & 3.4 & 19.4 \\
\hline & & & $2000-2007$ (100) & 11.7 & 7.0 & 16.4 & 5.5 & 17.5 \\
\hline \multirow{2}{*}{46} & \multirow{2}{*}{1180} & \multirow{2}{*}{ Bala } & $2000-2001(50)$ & 11.1 & 4.9 & 17.2 & 2.4 & 18.1 \\
\hline & & & $2000-2001$ (100) & 11.0 & 5.5 & 16.5 & 3.3 & 16.8 \\
\hline \multirow{2}{*}{50} & \multirow{2}{*}{1154} & \multirow{2}{*}{ Loggerheads } & $2000-2003(50)$ & 10.3 & 4.4 & 16.2 & 2.5 & 17.9 \\
\hline & & & $2000-2003(100)$ & 10.4 & 5.4 & 15.5 & 4.0 & 17.0 \\
\hline
\end{tabular}


Appendix Table A5

\begin{tabular}{|c|c|c|c|c|c|c|c|c|}
\hline $\operatorname{Rec}$ & Src_id & $\begin{array}{l}\text { Abbreviated station } \\
\text { name }\end{array}$ & $\begin{array}{l}\text { Time period \& } \\
\text { Depth }(\mathbf{c m})\end{array}$ & Mean $\left({ }^{\circ} \mathrm{C}\right)$ & $\begin{array}{l}\mathrm{S}_{\min } \\
\left({ }^{\circ} \mathrm{C}\right)\end{array}$ & $\begin{array}{l}\mathrm{S}_{\max } \\
\left({ }^{\circ} \mathrm{C}\right)\end{array}$ & $\begin{array}{l}\mathrm{D}_{\min } \\
\left({ }^{\circ} \mathrm{C}\right)\end{array}$ & $\begin{array}{l}\mathrm{D}_{\max } \\
\left({ }^{\circ} \mathrm{C}\right)\end{array}$ \\
\hline \multirow{2}{*}{60} & \multirow{2}{*}{1502} & \multirow{2}{*}{ Murlough } & $2002-2005$ (50) & 10.9 & 5.1 & 16.7 & 3.3 & 18.8 \\
\hline & & & $2002-2005(100)$ & 10.9 & 6.2 & 15.6 & 5.3 & 16.8 \\
\hline \multirow{2}{*}{61} & \multirow{2}{*}{1509} & \multirow{2}{*}{ Magherally } & $2000-2004(50)$ & 10.5 & 5.0 & 16.0 & 3.3 & 17.9 \\
\hline & & & $2000-2004(100)$ & 10.6 & 6.3 & 14.9 & 5.3 & 15.9 \\
\hline \multirow{2}{*}{63} & \multirow{2}{*}{1568} & \multirow{2}{*}{ St Angelo } & $2002-2010(30)$ & 10.8 & 4.1 & 17.5 & 1.1 & 20.5 \\
\hline & & & $2002-2010(100)$ & 11.0 & 5.7 & 16.4 & 3.8 & 17.4 \\
\hline \multirow{2}{*}{64} & \multirow{2}{*}{1532} & \multirow{2}{*}{ Annaghmore } & $2000-2004(50)$ & 11.2 & 6.1 & 16.3 & 4.4 & 18.2 \\
\hline & & & $2000-2004(100)$ & 11.2 & 7.2 & 15.3 & 6.0 & 16.5 \\
\hline \multirow{2}{*}{68} & \multirow{2}{*}{1517} & \multirow{2}{*}{ Ballywatticock } & $2000-2004(50)$ & 10.9 & 5.5 & 16.2 & 3.5 & 18.5 \\
\hline & & & $2000-2004(100)$ & 10.8 & 6.6 & 15.0 & 5.2 & 16.1 \\
\hline \multirow{2}{*}{70} & \multirow{2}{*}{1523} & \multirow{2}{*}{ Helens Bay } & $2000-2001(50)$ & 10.7 & 5.2 & 16.2 & 3.3 & 17.2 \\
\hline & & & $2000-2001(100)$ & 10.4 & 6.1 & 14.8 & 4.8 & 15.0 \\
\hline \multirow{2}{*}{76} & \multirow{2}{*}{1437} & \multirow{2}{*}{ Coleraine University } & $2000-2000(30)$ & 10.4 & 4.8 & 15.9 & 3.1 & 17.8 \\
\hline & & & $2000-2000(100)$ & 10.3 & 6.4 & 14.3 & 6.6 & 15.0 \\
\hline
\end{tabular}

